\title{
Municipal Antitrust Liability: Beyond Immunity
}

Over forty years ago the United States Supreme Court held in Parker v. Brown ${ }^{1}$ that the Sherman Antitrust Act ${ }^{2}$ does not apply to the activities of state governments. ${ }^{3}$ More recently, the Court held that the antitrust immunity granted to state governments in Parker does not automatically extend to local units of government. In City of Lafayette $v$. Louisiana Power \& Light Co., ${ }^{4}$ and more clearly in Community Communications Co. v. City of Boulder, ${ }^{5}$ the Court held that municipalities ${ }^{6}$ can be proper defendants under the Sherman Act.

The Court was, however, careful not to place municipalities in the same position as private antitrust defendants. It reserved the possibility that municipalities would not be subject to treble damages. ${ }^{7}$ It also allowed local governments in certain limited circumstances to share their states' immunity. ${ }^{8}$ Finally, the Court suggested that antitrust law restrictions might be less stringent when applied to local government. ${ }^{9}$ Nevertheless, the mere fact of mumicipal antitrust exposure was a drastic change from prior law. The City of Lafayette and City of Boulder decisions alarmed local government officials ${ }^{10}$ and stirred a wave of antitrust lawsuits against municipalities. ${ }^{11}$

For many years following City of Lafayette, appellate litigation in antitrust suits agamst municipalities focused on wliether the defendants

1. 317 U.S. 341 (1943).

2. 15 U.S.C. $\S \S 1-7(1982)$.

3. Parker, 317 U.S. at $350-52$.

4. 435 U.S. 389 (1978).

5. 455 U.S. 40 (1982).

6. This Comment employs the terms "municipality" and "city" to refer to all units of local government, such as counties, special districts, cities, townships, and parishes. See infra note 35.

7. City of Boulder, 455 U.S. at 56 n.20; City of Lafayette, 435 U.S. at 401-02. Congress has since provided that money damages may not be assessed against governmental antitrust defendants. Local Government Antitrust Act of 1984, Pub. L. No. 98-544, 98 Stat. 2750 (1984) (codified at 15 U.S.C. $\S \S 34-36$ (Supp. II 1984)).

8. See infra text accompanying notes $34-51$.

9. City of Boulder, 455 U.S. at 56 n.20; City of Lafayette, 435 U.S. at 417 n.48 (plurality opinion).

10. See, e.g., De Raismes, The Boulder Case: Caveat Polis, 24 MUN. ATT'Y 15 (1983); Driker \& Share, Antitrust Liability, 61 MicH. B.J. 426 (1982); Spiegel, Local Governments and the Terror of Antitrust, 69 A.B.A. J. 163 (1983); Yetter, Local Government Exemption from the Federal Antitrust Laws: Community Communications Co. v. City of Boulder, 56 FLA. B.J. 565 (1982); Young, Supreme Court Report, 68 A.B.A. J. 342, 344 (1982).

11. See, e.g., cases cited infra notes 211-16, 221-24, 227-31 \& 233-34. See generally Brennan, Local Government Action and Antitrust Policy: An Economic Analysis, 12 FordHAM URB. L.J. 405 (1984). 
were cloaked with their states' immunity. Few reported decisions reached the application of substantive antitrust doctrine to municipal defendants. ${ }^{12}$ The standards for determining immunity have now been fairly well settled. ${ }^{13}$ Courts must now begin to analyze a defendant municipality's liability when the municipality is held not immune. How will liabihty be determined? Courts will find little formal guidance; the Supreme Court has had little to say on the subject. Moreover, most proposals from commentators have failed to identify and incorporate all the necessary policy requirements. They either reveal strong biases toward local autonomy, ${ }^{14}$ or propose unworkable solutions. ${ }^{15}$

This Comment will formulate guidelines for analyzing antitrust liability of nonimmune municipal defendants. It attempts to remain faithful to what little the Supreme Court has said about the issue, while considering local autonomy and national antitrust policy.

Part I discusses the background law. Part II explains why existing doctrine is inadequate to sort out relevant concerns. Part III develops and justifies the proposed analysis, identifying three relevant inquiries. First, the court should determine whether the defendant is the appropriate governmental entity to take the challenged action. ${ }^{16}$ Second, the court should mquire whether the action imposes the type of anticompetitive evils that the Sherman Act was imtended to prevent. ${ }^{17}$ Third, the court must decide whether the activity effectively minimizes anticompetitive harm while furthering municipal goals. ${ }^{18}$ Part IV illustrates the proposed analysis witl hypothetical examples. Finally, Part V discusses whether the mumcipal antitrust issue is one of preemption or exemption.

\section{BACKGROUND LAW}

Parker v. Brown ${ }^{19}$ involved a challenge under section 1 of the Slierman Act to a raisin marketing program impemented by the State of Califorma in response to a raisin surplus. ${ }^{20}$ The purpose and effect of the

12. The California Supreme Court addressed this issue in December 1984 in Fisher v. City of Berkeley, 37 Cal. 3d 644, 693 P.2d 261, 209 Cal. Rptr. 682 (1984), prob. juris. noted, 105 S. Ct. 2653 (1985) (No. 84-1538).

13. See infra text accompanying notes $46-49$.

14. See, e.g., James, Municipal Defenses to Antitrust Liability, 6 U. ARK. LITTLE Rock L.J. 273, 291-96 (1983) (proposing nonliability for all reasonably necessary public welfare actions). See generally infra notes 198 \& 200.

15. Many, for example, would require local governments to establish formal procedures to establish the fairness of their decisionmaking. See infra text accompanying note 123. Others would require courts to undertake broad "balancing" inquiries into municipal goals. See infra note 184.

16. See infra text accompanying notes 145-58.

17. See infra text accompanying notes $159-81$.

18. See infra text accompanying notes 182-86.

19. 317 U.S. 341 (1943).

20. Id. at 344,350 . 
program was to elimmate price competition among raisin producers. ${ }^{21}$ The plaintiff raisin producer sought to enjoin enforcement of the program's competitive restraints. The Supreme Court refused to subject the plan to antitrust scrutiny. The Court reasoned that the Sherman Act was intended only to suppress anticompetitive conduct of individuals and corporations, not to restrain state government action. ${ }^{22}$ Thus, the Parker decision accords great weight to a state's sovereign riglit to regulate. ${ }^{23}$ The Court cautioned, however, that a state may not autlorize private anticompetitive behavior; only the action of the state itself merits antitrust immunity. ${ }^{24}$

For nearly thirty years, the Court left the Parker rule untouched. In the past ten years, however, a series of Supreme Court cases ${ }^{25}$ has developed the doctrine considerably by clarifying and restricting the scope of the "state action" which is immune to antitrust challenge. The Court has held that a mandate of the state legislature, ${ }^{26}$ or the state supreme court acting legislatively ${ }^{27}$ triggers Parker protection; lower state governing bodies must act pursuant to these mandates if they are to receive immunity. More precisely, the state's immunity may extend to both pub$\mathrm{lic}^{28}$ and private ${ }^{29}$ entities as long as the allegedly anticompetitive activity meets a two-part test. First, the activity must be "clearly articulated and

21. Id. at $346-48$.

22. Id. at $350-52$.

23. Id.

24. Id. at 351 .

25. See, e.g., Southern Motor Carriers Rate Conference v. United States, 105 S. Ct. 1721 (1985); Town of Hallie v. City of Eau Claire, 105 S. Ct. 1713 (1985); Community Communications Co. v. City of Boulder, 455 U.S. 40 (1982); California Retail Liquor Dealers Ass'n v. Midcal Aluminum, Inc., 445 U.S. 97 (1980); New Motor Vehicle Bd. v. Orrin W. Fox Co., 439 U.S. 96 (1978); City of Lafayette v. Louisiana Power \& Light Co., 435 U.S. 389 (1978); Bates v. State Bar, 433 U.S. 350 (1977); Cantor v. Detroit Edison Co., 428 U.S. 579 (1976); Goldfarb v. Virginia State Bar, 421 U.S. 773 (1975).

26. Hoover v. Ronwin, 104 S. Ct. 1989, 1995 (1984). "[W] hen a state legislature adopts legislation, its actions constitute those of the State, and ipso facto are exempt from the operation of the antitrust laws." Id. (citation omitted). See, e.g., New Motor Vehicle Bd. v. Orrin W. Fox Co., 439 U.S. 96, 109-11 (1978) (rejecting a Sherman Act challenge to California's Automobile Franchise Act under the state action exemption because it is a state system of regulation); Parker, 317 U.S. at 350-52 (rejecting a Sherman Act challenge to California's Agricultural Prorate Act).

27. See, e.g., Hoover v. Ronwin, 104 S. Ct. 1989, 1995 (1984) (rejecting a Sherman Act challenge to the bar admissions practices of the Arizona Supreme Court's Committee on Examinations and Admissions because the action of the Committee was attributable to the Arizona Supreme Court, stating "a decision of a state supreme court, acting legislatively rather than judicially, is exempt from Sherman Act liability as state action."); see also Bates v. State Bar, 433 U.S. 350, 359-63 (1976) (rejecting a Sherman Act challenge to an Arizona Supreme Court disciplinary rule prohibiting attorney advertising).

28. See, e.g., New Motor Vehicle Bd. v. Orrin W. Fox Co., 439 U.S. 96 (1976).

29. See, e.g., Southern Motor Carriers Rate Conference v. United States, 105 S. Ct. 1721, 1728 (1985) (private rating bureaus which prepare rate proposals for motor common carriers held immune from Sherman Act when acting pursuant to state legislative intent to permit collective ratemaking); Bates v. State Bar, 433 U.S. 350, 361 (1976) (state bar held immune from Sherman Act when enforcing state supreme court rule prohibiting attorney advertising). 
affirmatively expressed as state policy." 30 Second, it must be "actively supervised" by the state itself. ${ }^{31}$

The two-prong test implements Parker's warning that the state may not throw the cloak of its own immunity over private anticompetitive behavior. ${ }^{32}$ The "active supervision" prong prevents the state from delegating its immunity to private parties. Although it may authorize a private party to act as its agent, the state must remain the ultimate decisionmaker. The "pohicy articulation" requirement ensures that the state is making an affirmative decision to replace free competition with a comprehensive regulatory scheme. ${ }^{33}$

In City of Lafayette v. Louisiana Power \& Light Co., ${ }^{34}$ the Supreme Court for the first time faced the question of whether local governments ${ }^{35}$ share Parker immunity. ${ }^{36}$ The Court framed the question, as it had in Parker, as one of congressional intent. It found no evidence that Congress had specifically intended to exempt cities. In declining to infer an exemption, the Court relied on the Sherman Act's nature as a fundamental document. ${ }^{37}$ The only exemptions the Court had previously authorized under an implied intent rationale had rested on fundamental policies, such as the state sovereignty principle that had served as the basis for the Parker state action exemption. ${ }^{38}$ The Court held that

30. California Retail Liquor Dealers A.ss'n v. Midcal Aluminum, Inc., 445 U.S. 97, 105 (1980).

31. Id.

32. Parker, 317 U.S. at 351.

33. California Retail Liquor Dealers Ass'n v. Midcal Aluminum, Inc., 445 U.S. 97, 104-05 (discussing development of the policy articulation requirement); accord City of Lafayette, 435 U.S. at 413 (plurality opinion) (exempt local government activity must be "pursuant to state policy to displace competition with regulation or monopoly public service").

34. 435 U.S. 389 (1978). The City of Lafayette case generated five different opinions from the Court. Justice Brennan delivered a three-part opinion. Part I constituted the opinion of the Court, Justice Brennan joined by Justices Marshall, Stevens, Powell, and Chief Justice Burger. Parts II and III constituted a plurality opinion, Chief Justice Burger concurring only in Part I of the Brennan opinion. Chief Justice Burger delivered a separate concurrence, as did Justice Marshall. Justices Stewart and Blackmun delivered dissenting opinions.

35. In City of Lafayette and in City of Boulder, the Court's reasoning applies equally well to municipal and nonmunicipal forms of local government. Indeed, the Court often speaks in terms of "units of local government," City of Lafayette, 435 U.S. at 407.

36. Prior to City of Lafayette, lower courts had generally assumed that Parker immunity extended to political subdivisions. See, e.g., New Mexico v. Ameriean Petrofina, Inc., 501 F.2d 363, 370 n.15 (9th Cir. 1974). See generally Note, The Antitrust Liability of Municipalities Under the Parker Doctrine, 57 B.U.L. REv. 368, 379-80 (1977) (asserting that of the three pre-1975 cases reaching the issue, one assumed municipal immunity, one reached the same result with a more extensive analysis, and the third rejected immunity on the grounds of inadequate state authorization). But see id. at 380 (beginning in 1975, some courts scrutinized anticompetitive municipal activity more rigorously).

37. City of Lafayette, 435 U.S. at 398.

38. Id. at 400 . The Court also cited the Noerr-Pennington doctrine, which exempts from antitrust scrutiny concerted efforts to infiuence government action, such as lobbying. The fundamental principle underlying the Noerr-Pennington exemption is the constitutional right of petition with its correlative principle that open communication is necessary to representative democracy. Id. at 400 (discussing Eastern R.R. Presidents Conference v. Noerr Motor Freight, Inc. 
municipal autonomy implicated no such fundamental countervailing policies.

According to the City of Lafayette Court, the organic differences between governmental and private defendants did not place the former outside the intended scope of the antitrust laws. Their public service nature did not compel an implied exemption, the Court lield. Altliough local governments play a beneficial role in providing public services to their constituents, their interests are necessarily parocliial. They act to benefit their constituencies. Since inurncipalities are independent economic actors, they pose the same threats to the national econoiny that private corporations do. An unqualified exemption for local governinent would allow the sort of anticompetitive activities the Sherman Act was enacted to prolibit. ${ }^{39}$

A plurality of the City of Lafayette Court then considered whether cities, even if they were not exempt as cities, miglit derive immunity as agents of the state. The plurality reviewed the Parker line of cases dealing witl the scope of state action, observing that even state agencies do not have automatic Parker immunity. It acknowledged that inunicipalities sometimes act as instrumentalities of the state, and agreed that immunity would be appropriate in such circuinstances. The plurality concluded that cities, like administrative agencies, would have Parker innunity when acting "pursuant to state policy to displace coinpetition with regulation or monopoly public service."40 It adopted the lower court's test for state authorization: the subordinate governmental unit acts under the state's inandate when the state "legislature conteinplated the kind of action complained of."41 Absent such autlorization, lowever, a state's subdivisions must "obey the antitrust laws." 42

Lower courts and coinmentators struggled to determine the proper meaning of the City of Lafayette plurality decision for years. ${ }^{43}$ Any

365 U.S. 127 (1961) and UMW v. Pennington, 381 U.S. 657 (1965)). For a more detailed discussion of the Noerr-Pennington doctrine, see Comment, Affiliated Capital Corp. v. City of Houston: Local Governments and Antitrust Immunity, 35 BAYLOR L. REv. 791, 803 n.101 (1983). See generally P. AREeda \& D. TuRner, ANTitrust Law 202-05 (1978) ("Relationship of Noerr and Parker Immunities"); id. at 212.6 (Supp. 1982) (same); L. Sullivan, HANDBooK OF THE LAW OF ANTITRUST $\$ 238 d$, at 740-43 (1977).

39. City of Lafayette, 435 U.S. at 403-08.

40. Id. at 413 (plurality opinion).

41. Id. at 415 (quoting City of Lafayette v. Louisiana Power \& Light Co., 532 F.2d 431, 434 (5th Cir. 1976)). The plurality noted, however, that the municipality need not identify "a specific, detailed legislative authorization." Id.

42. Id. at 416 .

43. Many observers believed the decision would have a devastating impact upon local government. See, e.g., Bangasser, Exposure of Municipal Corporations to Liability for Violations of the Antitrust Laws: Antitrust Immunity after the City of Lafayette Decision, 11 URB. LAW. vii (1979); Note, Federal Antitrust Immunity: Exposure of Municipalities to Treble Antitrust Damages Sets Limit for New Federalism: City of Lafayette v. Louisiana Power \& Light Co., 11 CoNN. L. REv. 126, $139-41$ (1978). In any event, an exact interpretation of City of Lafayette remained elusive. 
doubts about the Court's commitment to the imposition of antitrust liability upon municipalities disappeared with the emergence of a full majority in Community Communications Co. v. City of Boulder, ${ }^{44}$ in which the Court held that even "home rule" cities-those which had received full rights of self-government from the state ${ }^{45}$-do not enjoy automatic Parker immumity. This holding narrowed the scope of the "state agency" exemption for mumicipalities. It affirmed that the challenged activities must be pursuant to a "clearly articulated and affirmatively expressed state policy" 46 and went further, demanding that the authorization be specific: the state legislature ${ }^{47}$ must not only have "contemplated the kind of action complained of," 48 but must have "contemplated the specific anticompetitive actions" 49 under attack. A general grant of power by the state will not confer Parker immunity; rather the state must "affirmative[ly] address[ ] . . . the subject." 50 By narrowing the circumstances under which a municipality can claim derivative state action immunity, the City of Boulder Court broadened the municipal antitrust exposure created in City of Lafayette.

The City of Boulder majority's affirmation of the City of Lafayette plurality placed municipal antitrust liability on sure doctrinal footing. ${ }^{51}$

Chief Justice Burger provided the plurality with the necessary fifth vote. City of Lafayette, 435 U.S. at 418 (Burger, C.J., concurring). The Chief Justice set up a dichotomy based on the anticompetitive activity. Id. at 418,420 . If the activity was a "traditional government function," $c f$. National League of Cities v. Usery, 426 U.S. 833, 852 (1976), overruled, Garcia v. San Antonio Metropolitan Transit Auth., 105 S. Ct. 1005 (1985), the municipality would be immune. If the activity was a "proprietary activity"- - the "running of a business enterprise," the municipality would face liability. While this test appears more favorable to cities than that of the plurality, the Chief Justice proposed a more stringent liability standard on nonimmune cities. He would have reaffirmed the test set out in Cantor v. Detroit Edison Co., 428 U.S. 579, 597 (1976), which required that anticompetitive activity be " "necessary in order to make the [state policy] work, "and even then only to the minimum extent necessary." " City of Lafayette, 435 U.S. at 426 (quoting Cantor, 428 U.S. at 597). Justice Marshall, a member of the plurality, concurred in this latter requirement. See id. at 417-18 (Marshall, J., concurring).

44. 455 U.S. 40, 57 (1982) (confirming the City of Lafayette plurality).

45. See, e.g., The Colorado Home Rule Amendment, Colo. Const. art. XX, $\$$, which confers upon municipalities "the full right of self-government in both local and municipal matters" and provides that state statutes may be "superceded by" local ordinances. The Colorado Amendment was cited and discussed in City of Boulder, 455 U.S. at 43 n.1, 44.

46. City of Boulder, 455 U.S. at 52. This is part of the test formulated in Midcal Aluminum, see supra note 20 and accompanying text, for state agencies and private entities claiming the protection of the state's Parker immunity.

47. Or, ultimately, its supreme court. See supra note 27.

48. City of Boulder, 455 U.S. at 55 (quoting City of Lafayette, 435 U.S. at 415 (plurality opinion)).

49. Id. at 55 .

50. Id.

51. The opinion did give rise to "vote counting" speculation about the permanence of the holding. Chief Justice Burger, concurring in City of Lafayette, switched to the dissent in City of Boulder, 455 U.S. at 55 n.18, presumably as a result of the rejection of his "proprietary" distinction, see supra note 43 . Justice White, who took no part in the City of Boulder decision, id. at 57, had dissented in City of Lafayette, and presumably remained unsympathetic to the City of Boulder 
In the following years the majority position in City of Boulder gained support culminating in a unanimous opinion in Town of Hallie v. City of Eau Claire. ${ }^{52}$ Town of Hallie made it easier for cities to share state immunity by removing two potential doctrinal requireinents for immunity - that cities need to be coinpelled by the state to undertake anticompetitive action and that they must be actively supervised by the state. ${ }^{53}$ Town of Hallie retained, however, the requirement that "the legislature contemplat[e] the kind of action complained of."54 Thus a city can be sued in antitrust unless it is acting pursuant to a specific and clearly articulated state authorization.

Many details of the immunity doctrine are now completely settled..$^{\text {ss }}$ However, the most significant issue remains: how to determine liability when a municipality is not protected as a state instrumentality. ${ }^{56}$ In City

holding. Justice Blackmun's move from the City of Lafayette dissent to the City of Boulder majority was not explained. At least one commentator had interpreted these shifts as indicating that the value of the City of Boulder holding as precedent was unclear. Yetter, supra note 10, at 566-67.

52. $105 \mathrm{~S}$. Ct. 1713 (1985). Much of the credit for this consolidation belongs to Congress. The City of Boulder opinion had left open the question of whether municipalities would be subject to antitrust law's treble damages. City of Boulder, 455 U.S. at $56 \mathrm{n} .20$. This possibility appeared to be a major concern of the dissenters. See City of Boulder, 455 U.S. at 65 n.2 (Rehnquist, J., dissenting); City of Lafayette, 435 U.S. at 440-41 (Stewart, J., dissenting); id., at 442-43 (Blackmun, J., dissenting). Congress's decision to exempt municipalities from all money damages for antitrust liability in the Local Government Antitrust Act of 1984, Pub. L. No. 98-544, 98 Stat. 2750 (1984) (codified at 15 U.S.C. $\S \S 34-36$ (Supp. II 1984)), may have been a major factor in persuading the dissenters to join the Town of Hallie decision.

53. Thus, cities have an easier path to immunity than private parties do. See supra text accompanying note 31 .

54. Town of Hallie, $105 \mathrm{~S}$. Ct. at 1719-21 (quoting City of Lafayette, 435 U.S. at 415). On its facts, Town of Hallie is a straightforward application of this standard. In Town of Hallie, the defendant municipalities held a monopoly on sewer treatment services. The municipalities refused to provide such services to neighboring townships unless they agreed to be annexed. They further refused to allow the townships' sewage transportation services to use its treatment facilities. The townships sued in antitrust, alleging unlawful extension of a monopoly, refusal to deal, and an unlawful tying arrangement. Id. at 1716.

The Supreme Court found that the state legislature had " "clearly articulated and affirmatively expressed' state policy to displace competition." Id. at 1719. In statutes authorizing sewage services, the state provided that such services may serve only such surrounding areas as the municipality chooses. In a closely related provision, the state permitted municipalities to tie sewage services to annexation - even permitting a city to condition services upon annexation when the city already had been ordered to provide services to unincorporated areas that resisted annexation. Id. at 1718-19.

55. The City of Boulder opinion left unresolved three issues. The remedy issue was resolved by Congress. See supra note 52. The issue of whether the active state supervision prong of California Retail Liquor Dealers Ass'n v. Mideal Aluminum, Inc., 445 U.S. 97, 105 (1980), applied to cities, see City of Boulder, 455 U.S. at 51 n.14, was decided in the negative by Town of Hallie, 105 S. Ct. at 1720-21. The third issue is the focus of this Comment.

56. Of course, in an attempt to avoid antitrust liability, municipalities are likely to seek specific authorization from the state legislatures for anticompetitive activities. It is unlikely a state legislature will be able to specifically authorize every potentially anticompetitive activity of every city in the state, however. Moreover, in some situations, the state legislature might have political reasons for not wanting to approve such actions. In California, for example, rent control ordinances have come under antitrust challenge. See Fisher v. City of Berkeley, 37 Cal. 3d 644, 693 P.2d 261, 209 
of Boulder, the Court specifically reserved this question. It stated that "certain activities which might appear anticompetitive when engaged in by private parties, take on a different complexion when adopted by a local government."57 This suggests a possible alteration of traditional antitrust analysis when the defendant is a municipality.

Lower court decisions have avoided this question, approaching municipal antitrust liability rather tentatively. Many decisions have been liberal, if not downright ingenious, in finding state authorization and thus in avoiding the liability issue. ${ }^{58}$ Indeed, some courts seem to impose antitrust liability on municipalities only for activities bordering on abuse of power or corruption. ${ }^{59}$ These cases have implicitly accepted Chief Justice Burger's "traditional government function" immunity suggestion. $^{60}$

As an increasing number of municipal antitrust defendants lose on the immunity issue, ${ }^{61}$ the liability issue will have to be confronted more

Cal. Rptr. 682 (1984), prob. juris. noted, 105 S. Ct. 2653 (1985) (No. 84-1538). The California legislature would be unlikely to approve such ordinances; it has several times come close to restricting them. See L.A. Daily J., May 8, 1985, at 4, col. 3; L.A. Daily J., Aug. 6, 1984, at 2, col. 2; L.A. Daily J., May 4, 1984, at 2, col. I.

57. City of Boulder, 455 U.S. at 56 n.20 (quoting City of Lafayette, 435 U.S. at 417 n.48 (plurality opinion)).

58. Lower courts have rejected the broader implications of City of Boulder, dismissing challenges to regulation and finding state authorization quite readily. See Goodrich, The Limits of Municipal Power, CAL. LAw., Mar. 1984, at 26, 27 (1984); see also Central Iowa Refuse Sys. v. Des Moines Metropolitan Solid Waste Agency, 715 F.2d 419 (8th Cir. 1983) (immunizing a joint venture in which 15 cities set up a landfill operation excluding private waste disposers because the legislature had declared it a "high priority", finding the exclusion to be a "necessary and reasonable" step in the project), cert. denied, 105 S. Ct. 1864 (1985); Pueblo Aircraft Serv. v. City of Pueblo, 679 F.2d 805 (10th Cir. 1982) (antitrust claims attacking the city's management of its airport dismissed on the grounds that the airport was operated for the benefit of the general public), cert. denied, 459 U.S. 1126 (1983); Hopkinsville Cable TV v. Pennyroyal Cablevision, 562 F. Supp. 543 (W.D. Ky. 1982) (granting exclusive franchise to cable TV provider is state-authorized anticompetitive behavior when statute authorizes requiring cable providers to secure franchises).

59. See, e.g., Westborough Mall, Inc. v. City of Cape Girardeau, 693 F.2d 733 (8th Cir. 1983). In Westborough Mall, the parties were competing to develop shopping malls and the city manager downzoned plaintiff's' property after site construction had begun, while simultaneously upzoning defendants' property. Other allegations included that the city promised, but did not grant, the necessary zoning to allow the defendants to proceed in secret, and that the downzoning of plaintiffs' site was in violation of local ordinances. Id. at 738-740. In Corey v. Look, 641 F.2d 32 (1st Cir. 1981), the city allegedly forced a parking lot operator out of business by, among other things, forbidding him to charge fees during all but six hours per week, granting free land to his competitor, blocking access to his lots, and refusing to enforce against trespassing cars. Id. at 34-35; see also Whitworth v. Perkins, 559 F.2d 378 (5th Cir. 1977) (conspiracy to keep plaintiff out of liquor business through zoning restrictions), vacated and remanded in light of City of Lafayette sub nom. City of Impact v. Whitworth, 435 U.S. 992 (1978), reinstated, 576 F.2d 696 (5th Cir. 1978), cert. denied, 440 U.S. 911 (1979); Schiessle v. Stephens, 525 F. Supp. 763 (N.D. Ill. 1981) (alleging a conspiracy to take plaintiff's property by eminent domain and convey it to competing developers).

60. City of Lafayette, 435 U.S. at 424 (Burger, C.J., concurring). See supra note 43.

61. See, e.g., Parks v. Watson, 716 F.2d 646 (9th Cir. 1983) (partial reversal of summary judgment for defendants in action alleging tying of city's zoning power to geothermal heating market); Campbell v. City of Chicago, 577 F. Supp. 1166, $1174-79$ (N.D. Ill. 1983) (denial of motion 
directly. But the Supreme Court has suggested that the antitrust analysis for municipal defendants "might" differ from that for private defendants. The next section argues that existing doctrine is indeed inadequate to analyze the anticompetitive consequences of municipal activities.

II

Traditional ANTITRUST ANALYSIS Is INAPPRopriate WHEN THE DEFENDANT IS A GOVERNMENTAL

UNIT

In City of Lafayette and City of Boulder, the Supreme Court was careful to point out that it was not suggesting that the defendants' actions violated the Sherman Act. The Court decided only that Parker immunity did not shield the municipal defendants; antitrust suits could proceed. Furthermore, the Court was aware that exposing municipalities to antitrust liabihty could put cities at grave risk. The Court therefore did not subject cities to the full brunt of antitrust doctrine; it provided a shield of ambiguity. It deliberately reserved the possibility that some aspects of existing antitrust doctrime would not apply to cities. Indeed, the Court twice suggested in a footnote, "[i]t may be that certain activities which might appear anticompetitive when engaged in by private parties, take on a different complexion when adopted by a local government."62 This observation, the Court's only words on the subject, appears to be an invitation to alter existing doctrine. ${ }^{63}$

This Comment's purpose is to develop a new analysis for municipal antitrust liability. Before doing so, however, it will be necessary to examine the adequacy of the traditional approaches. The following Section argues that these approaches, and the rationales underlying them, are singularly inappropriate for analyzing the anticompetitive effects of municipal activities.

Two methods of analysis govern section 1 of the Sherman Act: the per se rule and the rule of reason. The first step in section 1 analysis is to decide which rule is appropriate for the challenged activity. If the activity falls under the rule of reason, it is further analyzed to determine its effect on competition. But if it falls under the per se rule, it is assumed to

to dismiss in action alleging that taxicab licenses were distributed so as to give two companies $80 \%$ of market share in perpetuity).

One could argue that Town of Hallie represents a liberal finding of state-authorized immunity, and signals a retreat from City of Boulder. Under this view, municipalities will find it increasingly easy to prevail on the immunity issue. This Comment, however, suggests that the Town of Hallie approach is a rather straightforward application of the City of Boulder test. See supra note 54.

62. City of Boulder, 455 U.S at 56 n.20 (quoting City of Lafayette, 435 U.S. at 417 n.48 (plurality opinion)).

63. Justice Rehnquist, dissenting in City of Boulder, objected that "the lower courts . . . must now adapt antitrust principles to adjudicate Sherman Act challenges to local regulation." Id. at 65 . 
be anticompetitive and is held illegal without further analysis. ${ }^{64}$

\section{A. Inapplicability of the Per Se Rule}

The justifications for the per se rule's abbreviated antitrust analysis do not apply to post-City of Lafayette municipal antitrust cases. The purpose of any per se rule is to simplify litigation in cases which present familiar fact patterns. The Supreme Court places a challenged activity in the antitrust per se category when courts have had sufficient rule of reason experience $e^{65}$ to determine that the activity is categorically anticompetitive, or when any procompetitive benefit encompassed by the activity is sufficiently rare that the costs of identifying it exceed the benefit gained thereby. Essentially, the per ser rule is one of judicial efficiency. ${ }^{66}$

Municipal ordinances are thus singularly inappropriate for per se analysis because they represent unexplored antitrust terrain. ${ }^{67}$ Indeed, the Court has suggested that when the purpose of price fixing is to serve "public service or ethical norms," per se analysis is inappropriate. ${ }^{68}$

\section{B. Inadequacy of the Rule of Reason}

The rule of reason also provides inadequate analysis of the unique issues arising fron the antitrust liability of local governments. ${ }^{69}$ Despite its complexity, rule of reason analysis focuses on a narrow issue: "whether the challenged agreement is one that promotes competition or one that suppresses competition." "To effect of this formulation is to

64. National Soc'y of Professional Eng'rs v. United States, 435 U.S. 679, 692 (1978). See generally L. SullivaN, supra note $38, \S \S 63-72$, at $165-97$ (1977) (describing the development and current construction of $\S 1$ analysis).

65. Arizona v. Maricopa County Medical Soc'y, 457 U.S. 332, 349 n.19 (1982). If the Court has insufficient experience with an activity, it will use rule of reason analysis. Broadcast Music v. CBS, 441 U.S. 1, 24-25 (1979).

66. Continental T.V., Inc. v. GTE Sylvania Inc., 433 U.S. 36, 50 n.16 (1977). See L. SUllivaN, supra note $38, \S 70$, at 193.

67. Note that in United States v. Socony-Vacuum Oil Co., 310 U.S. 150 (1940), which created the per se rule against price-fixing, the Court justified its holding in part on the grounds that even if the prices set by private parties were reasonable, placing price-fixing power in private hands "would perpetuate unreasonable prices tomorrow since those prices would not be subject to continuous administrative supervision and readjustment in light of changed conditions." Id. at 221. This rationale is inapplicable when it is a government body setting prices. See generally Fisher v. City of Berkeley, 37 Cal. 3d 644, 667-71, 693 P.2d 261, 280-84, 209 Cal. Rptr. 682, $701-04$ (1984) (rejecting application of per se rules to Sherman Act challenge to municipal rent control ordinance), prob. juris. noted, 105 S. Ct. 2653 (1985) (No. 84-1538).

68. Arizona v. Maricopa County Medical Soc'y, 457 U.S. 332, 348-49 (1982).

69. See generally Fisher v. City of Berkeley, 37 Cal. 3d 644, 671-73, 693 P.2d 261, 284-85, 209 Cal. Rptr. 682, 704-06 (1984) (rule of reason inappropriate for Sherman Act challenge to municipal rent control ordinance because it was developed for private defendants and because to hold otherwise would result in liability for most municipal action), prob. juris. noted, $105 \mathrm{~S}$. Ct. 2653 (1985) (No. 84-1538).

70. National Soc'y of Professional Eng'rs v. United States, 435 U.S. 679, 691 (1978) (rejecting public safety justifications for ban on competitive bidding for engineering serviees); accord NCAA v. 
preclude arguments about whether, in a particular case, competition is in the public interest. That policy decision, the Court has held, has been made by Congress. ${ }^{71}$

The rule of reason's narrow inquiry would be heavily weighted against municipalities. The purpose of most municipal activity is to promote safety, health, and public welfare; this often requires market manipulation. ${ }^{72}$ Interferences with the market are inherently anticompetitive, and few such activities will have counterbalancing procoinpetitive effects. ${ }^{73}$

The Court has hinted that a broader inquiry inay be appropriate when the anticompetitive activity has public welfare goals. The Court has indicated approval of at least one lower court decision upholding private marketing restraints aimed at protecting public safety. ${ }^{74}$ Lower courts flirted for decades with the notion that certain private institutions might be coinpetent to regulate themselves notwithstanding the anticoinpetitive side effects of such behavior. The chief candidate for this privilege had been professional associations. ${ }^{75}$

Nevertheless, the Supreine Court's decisions in Goldfarb v. Virginia State $\mathrm{Bar}^{76}$ and National Society of Professional Engineers v. United States ${ }^{77}$ appear to have eliminated this privilege, although language in Goldfarb suggested that the usual rule of reason analysis might be broadened to take into account institutional ethical norms. ${ }^{78}$ Although the

Board of Regents, 104 S. Ct. 2948, 2962 (1984). But cf. Copperweld Corp. v. Independence Tube Corp., 104 S. Ct. 2731, 2741 (1984) (suggesting in dictum a broader rule of reason analysis).

71. National Soc'y of Professional Eng'rs v. United States, 435 U.S. 679, 692 (1978).

72. Posner, The Proper Relationship Between State Regulation and the Federal Antitrust Laws, 49 N.Y.U. L. REv. 693, 697 (1974); see also Fisher v. City of Berkeley, 37 Cal. 3d 644, 672, 693 P.2d 261, 284, 209 Cal. Rptr. 682, 705 (1984), prob. juris. noted, 105 S. Ct. 2653 (1985) (No. 84 1538).

73. See City of Boulder, 455 U.S. at 66-67 (Rehnquist, J., dissenting).

74. The Court has twice cited with approval Tripoli Co. v. Wella Corp., 425 F.2d 932 (3d Cir.) (en banc), cert denied, 400 U.S. 831 (1970), in which public safety considerations were held to justify vertical nonprice restraints under the then-governing Schwinn per se rule. Tripoli was cited in a footnote to National Soc'y of Professional Eng'rs v. United States, 435 U.S. 679, 696 n.22 (1978), as a possible limit to the narrowly drawn rule of reason. Tripoli also had been cited in Continental T.V., Inc. v. GTE Sylvania, Inc., 433 U.S. 36 (1977), as an example of a legitimate justification for vertical nonprice restraints in connection with that case's restoration of rule of reason analysis for such restraints. Id. at $55 \mathrm{n} .23$.

75. See generally Annot., 39 A.L.R. FED. 774, 789-95 (1978) (citing cases).

76. 421 U.S. $773,786-87$ (1975).

77. 435 U.S. 679 (1978).

78. See, e.g., Goldfarb, in which the Court wrote:

The fact that a restraint operates upon a profession as distinguished from a business is, of course, relevant in determining whether that particular restraint violates the Sherman Act. It would be unrealistic to view the practice of professions as interchangeable with other business activities, and automatically to apply to the professions antitrust concepts which originated in other areas. The public service aspect, and other features of the professions, may require that a particular practice, which could properly be viewed as a violation of the Sherman Act in another context, be treated differently. 
precise holdings of the two cases are debatable, ${ }^{79}$ at a minimum, the Court will not allow a profession to determine that competition itself is inappropriate. ${ }^{80}$ Nor has the Court yet recognized an instance in which professional ethics have justified a restraint with net anticompetitive results. ${ }^{81}$

Current antitrust doctrine, developed with private defendants in mind, would invalidate much municipal activity undertaken for the public benefit. Neither the per se approach nor the rule of reason approach can properly evaluate the unique relationship of local governments to the marketplace. The rationale of the two traditional approaches make them inappropriate to analyze the anticompetitive complexion of municipal activities.

This Comment will now explore new methods of analyzing municipal antitrust liability. It will parse the sources of liability, City of Boulder and City of Lafayette, to derive essential analytic factors. Then, it will offer an appropriate method of analyzing municipal antitrust liability.

III

\section{AN APPRopriate ANALYSIS}

\section{A. Sources of Guidance}

Before a new method of analysis can be developed, existing legal authority must be examined for criteria and limitations. The following sections explore three likely sources: Congress's intent in passing the Sherman Act in 1890, the Supreme Court's rationale for exposing municipalities to antitrust liability, and the context and language of the Court's suggestions in City of Lafayette and City of Boulder that traditional antitrust analysis may be altered when the defendant is a municipality. These three sources of authority afford varying amounts of help in illuminating applicable criteria and limitations for a new method of analysis. As will be shown, searching for congressional intent provides no insight, and examining the Supreme Court's reasons for imposing antitrust liability on municipalities suggests only that a fact-based and functional approach, rather than a rigid formula, must govern municipal antitrust

\section{U.S. at 788 n. 17.}

79. The precise holdings of both cases are narrow. In both cases, the professionals were defending restraints that directly inhibited price competition. Goldfarb involved minimum fees for attorneys set by the county bar assocation and National Society of Professional Engineers concerned the Society's ban on competitive bidding. Although both defendants argued that their actions benefited the public, it is likely the Court suspected the actions were primarily private price-fixing agreements, with at best ancillary public welfare aspects.

80. "[W]e may assume that competition is not entirely conducive to ethical behavior, but that is not a reason, cognizable under the Sherman Act, for doing away with competition." National Soc'y of Professional Eng'rs, 435 U.S. at 696.

81. See, e.g., id. at 696; Goldfarb, 421 U.S. at 786-88. 
analysis. The suggestions in City of Lafayette and City of Boulder are more fruitful and yield three factors that must be incorporated into any liability determination.

\section{Congressional Intent}

Antitrust liability is statutory. The search for an appropriate method of analysis must therefore begin with statutory interpretation and congressional intent. Facing the issue of whether the Sherman Act reached state action, the Parker v. Brown Court ${ }^{82}$ treated the question as one of congressional intent, deciding that the Congress in 1890 had not intended to interfere with a state's control over its officers and agents. ${ }^{83}$ The City of Lafayette Court repeated this methodology by asking whether that Congress had intended municipalities to be antitrust defendants. A closer examination of both cases reveals, however, that neither decision could have turned on congressional intent.

Any conclusion regarding the Fifty-first Congress's intent as to governmental antitrust liability is at best debatable and at worst fictional. The legislative history of the Sherman Act is notoriously ambiguous. ${ }^{84}$ The Parker Court's conclusion that Senator Sherman's intent was to restrain business and not government ${ }^{85}$ has been seriously challenged. ${ }^{86}$ At most, the Fifty-first Congress's intent was broad and sweeping. ${ }^{87}$

This is not to say that Congress specifically intended to proscribe anticompetitive state action-the subject was simply never considered. The Sherman Act was passed pursuant to Congress's commerce clause powers, and the commerce clause in 1890 did not reach state internal economic regulation. ${ }^{88}$ Thus, when the Fifty-first Congress passed the Sherman Act, no conflict could exist between state internal economic regulation and the commerce clause. ${ }^{89}$ The Parker Court's identification of the Fifty-first Congress's intent regarding state defendants half a cen-

82. Actually, the Parker Court was not faced with the issue; it raised it sua sponte.

83. Parker v. Brown, 317 U.S. 341, 350-52 (1943).

84. "[S]o incomplete and murky is the legislative record [of the Sherman Act] and so complex were the political maneuvers surrounding the enactment that it is impossible to glean from this history any clear-cut congressional intent." First, Private Interest and Public Control: Government Action, the First Amendment, and the Sherman Act, 1975 UTAH L. REV, 9, 11 (quoting M. FAINSOD, L. Gordon \& J. Palamountain, Government and the American Economy 445 (3d ed. 1959)).

85. Parker, 317 U.S. at 350-52.

86. Slater, Antitrust and Government Action: A Formula for Narrowing Parker v. Brown, 69 Niv. U.L. REv. 71, 83 (1974) (asserting that the Parker Court quoted legislative history out of context, and that instead the legislative history is silent as to governmental action).

87. Id.

88. See, e.g., United States v. E.C. Knight Co., 156 U.S. 1 (1895). In E.C. Knight, the Supreme Court rejected an antitrust attack on a Philadelphia sugar refining monopoly, holding that manufacturing was not in interstate commerce. Id. at 13 .

89. See generally City of Lafayette, 435 U.S. at 420 (Burger, C.J., concurring); Slater, supra note 86 , at $84-86$. 
tury after the Act was passed is therefore fictional. It follows that, although the Court still frames its opinions in terms of congressional intent, trying to discern legislative intent regarding municipal defendants nearly a century afterward is unrewarding. ${ }^{90}$

Nevertheless, the judiciary has great independence in Sherman Act interpretation. By virtue of the Act's broad language, ${ }^{91}$ its age, and its reflection of the nation's fundamental economic principles, ${ }^{92}$ the Act has attained quasi-constitutional status. ${ }^{93}$ The Court's antitrust decisions are based on economic principles and other judicially cognizable factors, and are not truly statutory interpretations. ${ }^{94}$ Therefore, the judicial interpretation has independent significance even without the confirmation of any underlying congressional intent.

\section{Functionalism}

Since examination of congressional intent provides no guidance for the analysis of municipal liability, the inquiry now turns to an examination of the doctrinal origins of the City of Lafayette nonimmunity. The examination first focuses on the differences between Parker, which granted immunity to state governments, and City of Lafayette, which denied immunity to local governments. The Parker holding created a formal exemption from Sherman Act liability for states. ${ }^{95}$ If the challenged activity was performed by, or at the behest of, the state, no further inquiry was necessary; the activity was exempt from the Sherman Act.

In contrast, City of Lafayette rejected any formulaic relationship between cities and states. The Court brushed aside arguments that cities

90. See, e.g., City of Lafayette, 435 U.S. at 394 (acknowledging that the Court is implying intent rather than interpreting it).

91. Id. at 406 n.32.

92. Senator Sherman suggested that the proposed bill federalized the existing common law of restraint of trade. See 21 CONG. REC. 2356-57 (1890).

93. The Act reaches the limits of congressional constitutional power and establishes "overarching and fundamental principles." City of Lafayette, 435 U.S. at 399. The Court has described the Act as "the Magna Carta of free enterprise," id. at 398 n.16, and has noted that as a "charter of freedom, the Act has a generality and adaptability comparable to that found to be desirable in constitutional provisions." Cantor v. Detroit Edison Co., 428 U.S. 579, 599 n.40 (1975) (plurality opinion). See generally Conant, The Supremacy Clause and State Economic Controls: The Antitrust Maze, 10 HASTINGs ConST. L.Q. 255, 261 n.39 (1983) (citing sources).

94. Of course, since the Act is statutory, Congress retains veto power over the Court's interpretations. Indeed, Congress has exercised that power in municipal antitrust doctrine. City of Lafayette and City of Boulder had left open the question of remedies against municipal defendants; the 98th Congress prohibited money damages in such cases. Local Government Antitrust Act of 1984, Pub. L. No. 98-544, 98 Stat. 2750 (1984) (codified at 15 U.S.C. $\S \S 34-36$ (Supp. II 1984)). Where Congress has not exercised its veto power, inquiries into congressional intent will rarely give meaning to issues left unresoived in judicial antitrust decisions.

95. See City of Boulder, 455 U.S. at 43 (asserting that Parker "announced" "the 'state action" exemption from Sherman Act liability"). 
were equivalent to states for federalism purposes, ${ }^{96}$ or that they were instrumentalities or creations of the state. ${ }^{97}$ However, in City of Lafayette's footnote forty-eight, the Court also rejected a characterization of cities as private parties for antitrust purposes. ${ }^{98}$ Indeed, it rejected any unitary characterization of local governmental units that would have yielded a rule comparable to that of Parker.

Instead, the Court focused on the actual relationship between local government and the national economy. A majority of the Court found that the public service goals of local governments do not warrant immunity from antitrust law. The Court analogized cities to private corporations: the former serve the interests of their citizens, the latter serve their shareholders. Neither one was "inherently more likely to comport with the broader interests of national economic well-being." "99 The Court pointed out that municipal activities can cause the type of harm that the Sherman Act was intended to prevent: cities can impose unnecessary monetary costs that will have an extraterritorial impact. In addition, they can obstruct regional efficiency. ${ }^{100}$ The Court, fearing economic Balkanization, worried that the multitude of independent local governments could, if unrestrained, seriously distort the national market economy and hinder efficient allocation of resources. ${ }^{101}$

At the same time, the City of Lafayette plurality recognized that cities sometimes act as state instrumentalities and therefore could deserve immunity under Parker. ${ }^{102}$ The plurality's analysis accommodates both the goals of the antitrust laws and the Parker exemption by instituting a fact-oriented test for determining municipal immunity in terms of state delegation. ${ }^{103}$ While the functionalism of the Court's approach resolves the immunity issue consistently with the case-by-case approach used in rule of reason analysis, it provides little structure to lower courts seeking standards for analyzing municipal antitrust liability in the absence of such immunity.

The Court's prescription for deciding when to deny immunity does, however, suggest a tone for the liability determination. The Court's functionalism, together with the freedom it delegated to lower courts by

96. City of Lafayette, 435 U.S. at 412 (plurality opinion); cf. Frug, The City as a Legal Concept, 93 HARV. L. REV. 1059, $1105-1117$ (1980) (discussing historical rejection of municipal autonomy).

97. City of Lafayette, 435 U.S. at 413 (plurality opinion); $c f$. Frug, supra note 96 at 1115 (discussing view of cities as creations of the state). Whilc referring to cities as "instrumentalities of the State," the Court was willing to acknowledge only that "municipalities may reflect state policy." Id. (emphasis added).

98. City of Lafayette, 435 U.S. at $417 \mathrm{n.48}$ (plurality opinion).

99. Id. at 403.

100. Id. at 404 .

101. Id. at 408; see also id. at 412-13 (plurality opinion) ("[S]erious economic dislocation could result if cities were free to place their own parochial interests above the Nation's economic goals.").

102. Id. at 413.

103. See supra text accompanying notes $40-42$. 
reserving judgment on the liability issue, ${ }^{104}$ extends an invitation to develop a functional theory of liabihity. The City of Lafayette Court's rationale sets the parameters: any theory must at least impose liability for the sort of anticompetitive conduct which concerned the City of Lafayette Court. To wit, it must prevent economic Balkanization, selfinterest, and inefficient allocation of resources. ${ }^{105}$ At a minimum, this argues against carving out an exception for legitimate government activity. ${ }^{106}$

\section{Guidance from Footnotes in City of Lafayette and City of Boulder}

The way in which the Court exposed municipalities to liability provides indirect clues as to the general tone of the desired liability analysis. Further inquiry into the origins of municipal liability yields more direct hints as to the analytic factors required. Those hints are contained in the City of Boulder opinion's footnote twenty and in the City of Lafayette opinion's footnote forty-eight.

\section{a. Footnote Twenty}

Footnote twenty in the City of Boulder opinion indicates that otherwise anticompetitive activities may "take on a different complexion when adopted by a local government" and suggests a comparison between National Society of Professional Engineers v. United States ${ }^{107}$ and Exxon Corp. v. Governor of Maryland. ${ }^{108}$ Professional Engineers held that private parties may not justify anticompetitive ineans with public health and safety ends. ${ }^{109}$ Exxon held the opposite with regard to states-that anticompetitive effect alone cannot invalidate a state statute aimed at public health or safety. ${ }^{10}$

A comparison of Exxon with National Society of Professional Engineers suggests that certain actors may accomplish their institutional goals despite some anticompetitive side-effects. In particular, states may determine that competition is not working in certain contexts, and may replace free markets with regulation, as Maryland did in Exxon. ${ }^{11}$ Pri-

104. For a discussion of the implications of footnotc 48 in City of Lafayette and footnote 20 in City of Boulder, see supra text accompanying notes 109-16.

105. See supra text accompanying notes $99-101$.

106. Cf. Fisher v. City of Berkeley, 37 Cal. 3d 644, 693 P.2d 261, 209 Cal. Rptr. 682 (1984), prob. juris. noted, 105 S. Ct. 2653 (1985) (No. 84-1538). See infra notes 234-36 and accompanying text.

107. 435 U.S. 679 (1978).

108. 437 U.S. 117 (1978).

109. National Soc'y of Professional Eng'rs, 435 U.S. at 693-95.

110. Exxon, 437 U.S. at 133 (rejecting Sherman Act challengc to a Maryland statute that prohibited oil producers and refiners from operating retail service stations within the state and required them to extend price breaks to all stations they supply).

111. Id. at 121, 133. 
vate trade associations, however-although theoretically able to engage in self-regulation with minor ancillary anticompetitive effects-may not determine that competition is itself undesirable. ${ }^{112}$

Thus, footnote twenty suggests that a city may, to the extent it is similar to a state, determine that competition conflicts with institutional goals and replace it with regulation. However, this privilege is limited to the extent of the city's governmental nature. This moves the analysis forward, but also raises additional questions. Under what circumstances may a governmental subunit regulate anticompetitively? Can all institutional goals constitute justification or is a city limited in the ends it may pursue anticompetitively? Is the type of regulation imposed relevant? Does the Sherman Act impose procedural restraints on such decisions? And, most perplexing, how and under what conditions can the defendant's governmental nature cause its anticompetitive actions to assume the "different complexion" alluded to in footnote twenty?

\section{b. Footnote Forty-eight}

Footnote forty-eight in City of Lafayette provides a clue to the last question. The footnote is the source of the statement-"It may be that certain activities which might appear anticompetitive when engaged in by private parties, take on a different complexion when adopted by local government" 113 - quoted in City of Boulder's footnote twenty. It cites with approval a 1974 article by Professor S. Paul Posner. ${ }^{114}$ The article recommended a radical cutback on Parker state immunity but acknowledged that "the difference between government action and private action may be of critical importance in terms of the principles and purposes of the antitrust laws." 115 Posner identified three reasons why private defendants are not permitted to use noneconomic factors to justify anticompetitive actions under the rule of reason, but then observed that these reasons do not apply with equal force to government actions. Footnote forty-eight suggests the Court may find these persuasive as ways in which otherwise anticompetitive activities "take on a different complexion when adopted by local government."116 In other words, Posner has identified three anticompetitive dangers that are not relevant to government action. This Comment will explore each of Posner's three dangers-judicial noncompetence, self-interest, and power concentrationin order to distill principles as to when government involvement gives a different complexion to an anticompetitive activity. In turn, this Com-

112. See supra text accompanying notes $74-81$.

113. City of Lafayette, 435 U.S. at 417 n.48 (plurality opinion).

114. Posner, supra note 72. Note that Posner was discussing state regulation, not that of local government.

115. Id. at 705.

116. City of Lafayette, 435 U.S. at 417 n.48 (plurality opinion). 
ment builds upon these three dangers to identify three factors critical to its municipal antitrust liability analysis-fair procedures, self-interest, and representation.

i. Judicial noncompetence to make policy decisions. One of the anticompetitive dangers Posner identified is lack of judicial competence to balance competing legitimate policies. This is the justification for the narrow articulation of the rule of reason in National Society of Professional Engineers: anticompetitive effects are balanced against procompetitive effects only; the courts are institutionally incapable of determining when public interest goals justify anticonipetitive measures. ${ }^{117}$ This limitation on the judiciary derives from the lessons learued during the Lochner era, when the Supreme Court engaged in economic policynuaking under the guise of substantive due process. ${ }^{118}$ Such judicial activisnu is now eschewed as usurping the role of the legislature. ${ }^{119}$

When the restraint on competition is inpposed by state regulation, however, Posner argues that the court need not engage in standardless evaluations of purportedly beneficial goals in order to consider the full range of justification arguments. When the defendant is a sovereign state, its decisions may be accorded full deference, because the state is presumed to have undertaken the required balancing itself. ${ }^{120}$ Balancing policy objectives, while outside judicial competence, is within a legislature's special expertise. Thus, the anticompetitive dangers posed by allowing justifications for anticompetitive behavior by private parties is reduced when the defendant is a state government.

Although the Supreme Court apparently approves Posner's discussion of how a defendant's governmental nature can alter an activity's anticompetitive complexion, his arguments carry less force when the defendant is a municipality rather than a state. Local governmental units are less conpetent than states to make policy decisions independently, not only because they lack sovereignty, ${ }^{121}$ but also because they are smaller. In large legislative bodies, the multiplicity of factions and issues provides some assurance of overall fairness because different legislative measures will generate different coalitions. These shifting and temporary alliances will serve to distribute power and promote cooperation. By contrast, in the councils typical of local governments, the smaller number

117. Posner, supra note 72, at 705 n.45; see also City of Boulder, 455 U.S. at 65-66 (Rehnquist, J., dissenting).

118. The Lochner era refers to a period in the first decades of this century, during which judges were willing to invalidate legislation with which they disagreed, using the doctrine of substantive due process. The case of Lochner v. New York, 198 U.S. 45 (1905), which epitomized the era, provided a name for the period. See generally J. NowaK, R. Rotunda \& J. Young, Constitutional LAW 436-43 (1983); L. TRIBE, AMERICAN CONSTITUTIONAL LAW $\$ \S 8-2$ to 8-6, at 434-49.

119. See City of Boulder, 455 U.S. at 67.68 (Rehnquist, J., dissenting).

120. Posner, supra note 72 , at 706.

121. City of Boulder, 455 U.S. at 50-51; City of Lafayette, 435 U.S. at 412 (plurality opinion). 
of factions and issues makes more likely the formation of permanent and possibly corrupt majorities, effectively disenfranchising minorities. ${ }^{122}$

Local governments are more competent to balance policy factors than private self-regulators, however, at least to the extent the local entities bear the incidents of government-representative democracy, legislative processes that give opportunities for direct participation, fact finding, and responsibility for public safety and health. Thus, a municipality's institutional legitimacy to balance public policy goals will lie between that of state governments and that of a private party.

This legitimacy is key to the inquiry into municipal antitrust liability. To the extent a court can trust a city's integrity in balancing the goal of free competition against public welfare goals, it can defer to municipal activity with some anticompetitive side effects. In the absence of a formal test for municipal legitimacy, however, a court would have to examine a city's decisionmaking procedures for indicia of governmental legitimacy.

Some commentators have suggested a "fair procedures" component to municipal antitrust liability analysis which would reflect this concern for governmental legitimacy. ${ }^{123}$ These proposals would place upon defendants, in each instance, the burden of proving the fairness of the decisionmaking procedures leading up to the challenged action. ${ }^{124}$ Though theoretically appealing, this approach is fraught with practical obstacles. Antitrust litigation is already overly complex; inquiries into municipal procedures would further coinphicate trials. The investigation and analysis required would demand political expertise outside the credentials of most antitrust attorneys. Furthermore, most local govern1nents employ relatively informal procedures. Even the fairest and most representative local government inay not be able to prove in court that its decisions were evenhanded. ${ }^{125}$ A fair procedures requirement, then, would force local governments to preserve a record of their decisionmaking. ${ }^{126}$ Most important, it is inappropriate to impose procedural requireinents on local governunents through antitrust law, which offers no

122. See Rose, Planning and Dealing: Piecemeal Land Controls as a Problem of Local Legitimacy, 71 Calif. L. Rev. 837, 853-57 (1983). Professor Rose discusses the theories of congressional legitimacy argued by Madison in The Federalist No. 10, and summarizes modern writers who argue that these bases of legitimacy are often absent in local government. She defines two elements of legitimacy: (1) fairness-that all parties prevail occasionally; and (2) due consideration-that decisionmakers take the time to consider the public welfare. Id. at 854-55.

123. See, e.g., Brennan, supra note 11, at 415-17, $432-34$ (proposing "procedural integrity" test); Cirace, An Economic Analysis of the "State Municipal Action" Antitrust Cases, 61 TEX. L. REV. 481, 498 (1982) (proposing standard of "high standards of ethical conduct.").

124. See, e.g., Brennan, supra note 11, at 432-34; Cirace, supra note 123, at 498.

125. See City of Lafayette, 435 U.S. at 437 (Stewart, J., dissenting) (asserting that state statutes often have little legislative history). City ordinances will a fortiori have obscure origins.

126. Cf. Posner, supra note 72 , at 715 , proposing that state legislatures be required to consider antitrnst issues on record so that decisions will be subject to both political and judicial review. 
obvious source of standards. If local political processes have broken down, litigants should avail themselves of more appropriate doctrines, such as state tort theories or 42 U.S.C. $\S 1983 .{ }^{127}$

Nevertheless, any method of municipal antitrust liability analysis should provide some screen for grossly illegitimate local actions without complicating litigation; this would enable courts to feel more confident in deferring to that decisionmaker's policy choices. Courts could thereby avoid balancing antitrust goals against other public welfare goals-an inquiry to which judicial expertise does not extend. Thus, Posner argues that justifying anticompetitive restraints with social welfare benefits poses less threat to antitrust goals when the actor is a state government. The Supreme Court presumably accepts the thrust of this argument as apphed to local government defendants, but its applicability depends on the legitimacy of the defendant's decisionmaking process. Accordingly, local governments should be permitted to justify anticompetitive activities with social welfare benefits, but some very narrow inquiry ${ }^{128}$ into the decisionmaking process must also be permitted.

ii. Self-interest. Another danger in allowing a defendant to justify an activity with a net anticompetitive effect is self-interest. The decisionmaker's self-interest is likely to bias its balancing of competition against pro-social goals. ${ }^{129}$ In particular, private actors competing with the decisioninaker are most likely to be stilled. ${ }^{130}$ When the balancing is

127. 42 U.S.C. $\S 1983$ (1982) implements the fourteenth amendment and applies the due process clause of the fifth amendment, as well as other constitutional and federal statutory provisions, to state and local government. See, e.g., Westborough Mall, Inc. v. City of Cape Girardeau, 693 F.2d 733, 740 (8th Cir. 1982) ( $\$ 1983$ ), cert. denied, 461 U.S. 945 (1983); id. at 742 (constitutional conspiracy); id. at 747 (interference with contract); Kurek v. Pleasure Driveway \& Park Dist., 557 F.2d 580, 584 (7th Cir. 1977) ( $\$ 1983$ and other federal statutes), vacatcd and remanded in light of City of Lafayette, 435 U.S. 992 (1978), reinstated as to antitrust issues, 583 F.2d 378 (7th Cir. 1978), cert. denied, 439 U.S. 1090 (1979); Hopkinswille Cable TV v. Pennyroyal Cablevision, 562 F. Supp. 543, 544 (W.D. Ky. 1982) (due process and state contract claims); Schiessle v. Stephens, 525 F. Supp. 763, 765-66 (N.D. Ill. 1981) (\$ 1983, common law conspiracy, and tortious interference with contract).

128. To avoid overburdening defendants and the litigation process, this test for legitimacy should be limited. It should not be imposed in every case. The initial burden should not be on defendants. It should test not for a high level of fairness, but only for basic elements of legitimacy. In this way, the basic governmental nature of the decisionmaker remains a requirement for legitimacy, but litigation would not be needlessly complicated. The proposed analysis attempts to meet these criteria by assuming fair procedures, but allowing plaintiffs to argue that the challenged action has an unspoken private anticompetitive purpose. See infra pp. 1854-55.

129. Posner, supra note 72 , at 706.

130. Self-interest was probably the main concern of the Court in the trade association selfregulation case of Fashion Originators' Guild of America v. FTC, 312 U.S. 457 (1941). In that case, women's clothing designers and manufacturers combined to form the Fashion Originators' Guild of America [FOGA]. FOGA organized a boycott of so called style pirates-manufacturers who copied the original clothing styles of others. The Federal Trade Commission brought an antitrust action against FOGA, and FOGA attempted to argue that its action benefitted both FOGA members and the public. The Court upheld the exclusion of evidence on this point. It did not deny that the style pirates' conduct was antisocial, nor even that the anticompetitive effects of the boycott were 
done by state government, Posner argues, this bias is removed because the state regulatory agency will not have an economic interest in the decisionmaking. ${ }^{131}$

Posner's view of the state as a neutral decisionmaker may be oversimplified, and local governments may often have economic stakes in their actions. But the Supreme Court's citation to Posner suggests that it accepts the argument that actions by a disinterested regulator may reduce anticompetitive injury. ${ }^{132}$ Thus, to the extent a municipality's anticompetitive action inures to its own direct economic benefit, it merits no more deference than that accorded a private party. But to the extent the municipality is disinterested, ${ }^{133}$ its action has a less anticompetitive complexion and resembles more closely that of a state government. Selfinterest should be a second factor, then, in evaluating municipal legitimacy for purposes of antitrust liability.

iii. Power concentration. The third anticompetitive harm that Posner identified in allowing justifications for anticompetitive activities is the increased economic power conferred on the privileged party. When this party is the state government, however, Posner argues that its responsibility to the electorate makes the power concentration less offensive to antitrust goals. ${ }^{134}$

While Posner does not elaborate on this argument, three factors justify the conclusion that the public power held by state government poses less harm to anticompetitive goals than does private power. First, privately-held power is less hikely to be used in the public interest, justifying a presumption against the validity of noneconomic justifications for a given restraint. Second, private economic concentrations are more likely to be permanent. Most local governments are fiuid, subject to institutional checks and balances and pohtical turnarounds. Power blocks are likely to break up and reahign. Policies are likely to change, preventing market lock-up. The third reason derives from the antitrust goal of atomization of economic power. ${ }^{135}$ Governmental consolidation of economic power may actually provide some benefits associated with a multiplicity of economic actors. These benefits result not only because shifting political factions will alternate control of government apparatus, but also

warranted by the social good attained thereby. The Court simply disregarded these arguments. Its concern was that the sanction was chosen by the Guild, and had the effect of stifling competition from nonmembers. The Guild, being self-interested, was not permitted to assume the role of policing "style piracy." Id. at $465,467-68$.

131. Posner, supra note 72 at 706.

132. City of Boulder, 455 U.S. at 56 n.20.

133. Of course, every municipal action has some benefit to the city. The distinction to be made is between actions that benefit the citizens of a city and those that directly increase revenues to the city itself.

134. Posner, supra note 72, at 706.

135. See Copperweld Corp. v. Independence Tube Corp., 104 S. Ct. 2731, 2741 (1984). 
because the representational nature of government provides voters with economic clout they would otherwise be denied. Thus, a concentration of power that would violate the antitrust laws in private hands may assume a less anticompetitive complexion when held by a state government.

Posner's argument supporting state action can justify municipal, anticompetitive decisions as long as the competition restrained is only that among the city's citizens. The citizens presumably have opportunities to influence municipal decisions, as well as opportunities for political redress. ${ }^{136}$ The mjury suffered differs little from that borne by losers of other political battles. Where the losers are not within the city, however, the city's power loses its representational character and resembles private power. Thus, the relationship between the governmental decisionmaker and the complainant should be a third factor in assessing anticompetitive harm from municipal activities.

In City of Lafayette, however, the Court rejected in broad language the argument that political redress can justify anticompetitive actions by cities. ${ }^{137}$ But the Court only discussed the pliglit of nonresidents affected by mumicipal actions, and of state citizens suffering from the anticompetitive actions of domestic corporations. In botl situations, the Court rejected the possibility that political redress by the state could justify the anticompetitive injury, but did not directly consider the case in whicli the complainant was a resident of the offending governmental unit. ${ }^{138}$ This distinction, combined witli the Court's favorable citation of Posner, suggests that the anticompetitive complexion might be lessened when the complainant lias a voice in tlie decisionmaking process.

\section{c. Conclusion}

City of Lafayette footnote forty-eiglit and City of Boulder footnote twenty invite a metlod of analysis of municipal antitrust liability that differs from existing analysis for private parties. Although these two cryptic footnotes are the Court's sole word on the subject, they do provide some guidance. A careful reading suggests that any sucli analysis must be fact oriented and functional. The Court's favorable reference to the Posner article in City of Lafayette's footnote forty-eiglit suggests tliree questions which lielp to identify whether municipal anticompetitive

136. To the extent such opportunities do not actually exist, the proper remedy lies outside antitrust law. See supra text accompanying note 127.

137. Congress "did not leave this fundamental national policy [competition] to the vagaries of the political process, but established a broad policy . . . which would guarantee every enterprise the right to exercise 'whatever economic muscle it can muster,' without regard to the amount of influence it might have in local or state legislatures." City of Lafayette, 435 U.S. at 406-07 (quoting United States v. Topco Assocs., 405 U.S. 596, 610 (1972)).

138. Id. 
actions are generating reduced anticompetitive harms: (1) did the decisionmaking process have fair procedures? (2) does the action inure to the municipality's self-interest? (3) are the parties who are harmed within the municipality's jurisdiction? The factors identify the dangers that most troubled the City of Lafayette Court when it denied Parker immunity to local governments.

In particular, the Court was worried about economic harm to direct competitors of the municipality, ${ }^{139}$ private economic profit by the municipality, ${ }^{140}$ and economic discrimination against customers outside the municipality's jurisdiction. ${ }^{141}$ These anticompetitive evils are precisely those identified by the self-interest and representation factors. The fair procedures factor addresses some of the concerns underlying the Court's focus on sovereignty. ${ }^{142}$ The three analytic factors must be mcluded in any new liabihty analysis. The next section develops a method of analyzing when anticompetitive activities by nonimmune local governments should result in antitrust liability.

\section{B. Proposed Analysis}

If a muncipal defendant is not entitled to inmunity under City of Boulder, a court must determine whether the mumicipality has violated the antitrust laws. If the city raises no special justifications, it should be treated as a private party. But if it claims public welfare justifications, the court must determine how the city's governmental status affects its liability. More precisely, the court must determine whether and how the city's public welfare purposes can excuse the anticompetitive effects of its action. The following method of analysis guides that determination by providing a framework for evaluating the considerations made relevant by the City of Boulder and City of Lafayette opinions, existing antitrust doctrine, and primciples of local government. The analysis directs three broad inquiries. First, there must be a determination of whether the city is the appropriate governmental unit to handle the problein. If the answer to this first inquiry is in the negative, the defendant should be treated as a private party. Otherwise, the analysis moves on to the second inquiry, which asks whether the government's action is within the bounds of the government's legitimacy to displace competition. An affirmative answer to this second question functionally will demonstrate the city's competence and legitimacy with regard to the challenged activity; the governinental nature of its acts will give them a nonanticompetitive complexion and remove them from the Sherman Act prohibition.

139. Id. at 403-04.

140. Id. at 403 .

141. Id. at 404 .

142. Id. at 412 . 
However, when the anticompetitive actions have the attributes of private rather than governmental actions, there should be a third and final inquiry: has the city chosen the least anticompetitive alternative? Each inquiry will now in turn be explicated.

\section{The City as Appropriate Actor}

When a social problem demands a resolution with anticompetitive effects, City of Lafayette and City of Boulder establish a general preference that the resolution be directed by the state. When a city undertakes anticompetitive regulation, therefore, it must overcome this preference by establishing that it, rather than the state, is the appropriate governmental unit to identify and to resolve the problem. Whether or not the city is the appropriate actor depends on whether it has identified a local nonanticompetitive goal. Thus, this initial inquiry consists of three elements: identification, localness, and a nonanticompetitive goal. As will be shown, the local autonomy concerns of cities as well as the procedural fairness concerns of those who must shoulder the anticompetitive effects of a city's activities must be considered. If the city cannot satisfy this inquiry, it should be treated as a private party.

\section{a. Nonanticompetitive Goal}

If a city replaces competition with regulation or monopoly service, it should have a good reason. It must therefore be required to explain how the free market failed to fulfill the city's desires. Either the city should demonstrate that there had been a market failure that motivated the challenged response, or it should identify nonanticompetitive social norms ${ }^{143}$ that the free market was unable to satisfy. ${ }^{144}$ As will be seen, this requirement places few substantive restrictions on municipalities. It does, however, force them to assert their governmental legitimacy by defining their governmental goals.

The first way to justify regulation of the free market would be to show that the regulation actually served to compensate for a market failure. ${ }^{145}$ A market failure is simply a substantial deviation from the per-

143. The term nonanticompetitive describes not a norm that is necessarily procompetitive, but rather one that is not purposefully anticompetitive.

144. Some commentators suggest building social norms into the market definition, so that the failure of the free market to comport with those norms constitutes a market failure. See, e.g., Cirace, supra note 123, at 493 (positing a reformulated theory of natural monopoly which includes questions of public policy and equity).

145. Antitrust doctrine incorporates the concept of market failure in several ways. A market failure can be critical to a court's choice between rule of reason and per se analysis. Thus in Broadcast Music, Inc. v. CBS, 441 U.S. 1 (1979), an arrangement which fit within the price-fixing rubric was analyzed under the rule of reason because high transaction costs-a market failuremade free competition logistically impossible. Market failure is also a standard justification within rule of reason analysis itself. Id. But cf. National Soc'y of Professional Eng'rs v. United States, 435 
fect competitive market. ${ }^{146}$ For example, an ordinance requiring restaurants to post menus in their windows can be explained as a response to an "information barrier"-consumers cannot choose or bargain unless they know the price at which a restaurant is offering its product. Hospital regulation may be justified because the high patienthospital ratio tends to ehminate interhospital competition, making hospital care a natural monopoly. Similarly, housing shortages may be caused by high entry barriers, as when most of a city's open space has been occupied and increased housing demand can be met only by purchasing and demolishmg existing low-density housing and replacing it with highdensity housing.

The proposed analysis goes further, however, and would allow a city to regulate even when perfect market conditions exist, as long as it identifies a nonanticompetitive goal which the market did not satisfy. The only restramt is that the goal must not have the specific intent of stilling competition. This does not mean that the challenged activity cannot have strong anticompetitive consequences. ${ }^{147}$ Rather, the goal must not itself constitute protectionism - a desire to protect the city or its resident businesses from competitors.

The foregoing definition of nonanticompetitive goal is tailored to two doctrines of constitutional dimension-avoidance of the substantive due process of Lochner-ism, ${ }^{148}$ and consistency with the national antitrust laws pursuant to the supremacy clause. In order to avoid the evils of the Lochner era, cities must be free to define their own policies, even if these policies deviate from goals of the ideal competitive market. In opening cities to muncipal antitrust liabihty, the Supreme Court did not renove cities' basic legislative prerogative of defining their own social welfare policies. Accordingly, the proposed analysis itself places no substantive limits on municipal goals. ${ }^{149}$ Substantive limits may, however, be placed on municipal goals by the Sherman Act's procompetitive mandate. A city may not advance a goal that is in intrinsic opposition to the national policy of free competition. The Sherman Act limit avoids sub-

U.S. $679,689-90$ (1978) (concerns about the special characteristics of a market should be addressed to Congress).

146. The four attributes of a competitive market are (1) an infinite number of buyers and sellers; (2) standardized products; (3) free resource mobility; and (4) perfect knowledge. Cirace, supra note 123, at 491. Traditionally, a market failure is said to occur when one of these conditions is not present. For a discussion of market failure in the context of local governments, see $i d$.

147. Such consequences are addressed in the second and third inquiries in the proposed analysis.

148. It has been noted that "[a]lthough substantive due process was supposedly consigned to oblivion . . . , it is alive, well, and traveling incognito in the narrow state action area." Cirace, supra note 123, at 484 . On substantive due process and Lochner generally, see J. NowAK, R. ROTUNDA \& J. YOUNG, supra note 118, at 436-51.

149. Of course, existing limits are not removed. Cities may not, for example, advance goals in opposition to federal antidiscrimination laws, nor act outside their state charters. These and other external limits should not, however, be enforced through an antitrust lawsuit. 
stantive due process problems because it derives from an external substantive source-federal law, dominant under the supremacy clause.

The distinction between an impermissible protectionist goal and a permissible goal with anticompetitive consequences can be most clearly illustrated with examples. An example of the former is downzoning one developer's land to protect another developer from competition. ${ }^{150}$ An example of the latter is a norm of citywide mass bus transportation at uniform prices. In a perfectly competitive market, a low-density area of the city (with correspondingly low transit use) would either attract no bus lines, or would suffer higher fares. Neither alternative is consistent with the articulated norm. The norm is permissible because it does not have the specific intent of stilling coinpetition between bus lines. Thus, the city would be justified in interfering with the market to ensure uniformity and availability.

A more coinplex example illustrates the distinction more clearly. Consider, on the one hand, a zoning regulation that requires all stores on an avenue to be within a certain size limitation, and, on the other hand, a regulation which bans chainstores. The first regulation has an arguably permissible purpose despite anticompetitive effects. Its permissible purpose would be to promote norms of neighborhood quality-it may be argued that it preserves an old-fashioned character, allows multiple proprietary business opportunities, increases neighborhood diversity, and promotes more personal customer-retailer relations despite limiting coinpetition to stores of a certain size. ${ }^{151}$ The second regulation, however, would be impermissibly protectiomst. It denies an entire line of competition to customers, proprietors, and potential franchisees rather than merely limiting the form of the competition. Its purpose is intrinsically anticompetitive.

\section{b. Identification}

The municipal defendant need only articulate its norms in response to litigation. Although the procedural fairness concerns suggested by City of Lafayette footnote forty-eight ${ }^{152}$ require that the city be acting for a valid public purpose, this analysis does not require the city to demonstrate its bona fides with legislative history. A screen for fair procedures can be effected without imposing impractical recordkeeping requirennents

150. See, eg., Westborough Mall, Inc. v. City of Cape Girardeau, 693 F.2d 733 (8th Cir.), cert. denied, 461 U.S. 945 (1983); Whitworth v. Perkins, 559 F.2d 378 (5th Cir. 1977), vacated and remanded in light of City of Lafayette sub nom. City of Impact v. Whitworth, 435 U.S. 992 (1978), reinstated, 576 F.2d 696 (5th Cir. 1978), cert. denied, 440 U.S. 911 (1979).

151. The ordinance might not, in fact, achieve these goals effectively. If that is the case, the ordinance will presumably be repealed by the municipality. It is not the role of antitrust law to have judges inform municipalities how best to implement their goals.

152. See supra pp. 1845-50. 
on all municipal actions ${ }^{153}$ by giving the plaintiff an opportunity to prove that the articulated goal is a sham. Absent such a showing, the defendant city's asserted goal would be accepted as its true purpose.

The suggested analysis would allow the plaintiff to prove the city's motivation was to confer not public but private benefit. Once the city shows a local nonanticompetitive goal, the burden of proof would shift to the plaintiff to show either an absence of the alleged public welfare purpose or an intent to confer the displaced competitive gains on the private defendants. As long as the proof burden is on the plaintiff, this rebuttal option would rarely tax judicial resources, and would not create a de facto requirement for municipalities to generate legislative history. It would, however, place some limits on the ability of private parties to use municipal structures to interfere with coinpetitive inarkets for private economic gain, thereby vindicating the procedural fairness concern.

A difficult question raised by this analysis is how the municipal purpose is to be determined. In constitutional adjudication, the concept of legislative intent has eluded definition. Current jurisprudence in this area avoids detailed inquiry into legislative history and substitutes as a test for purpose whether the challenged action is narrowly tailored to the purported purpose. ${ }^{154}$ A tight fit between ends and means implies the asserted end is honest. ${ }^{155}$ This Coinment recoinmends a similar approach. Attempts to glean intent from the generally sparse or nonexistent legislative history of municipal decisionınaking are likely to prove frustrating and arbitrary.

The utility of this more functional ends/means test can be dernonstrated by applying it to the previous discussion of land-use hypotheticals. In the hypothetical ban on chainstores, the defendant city might assert in litigation that its purpose was not protectionism, but the prevention of certain evils commonly associated with chainstores, such as insensitivity to local architectural styles, parking congestion, or litter problems. If these are the real goals, however, the ordinance is a poor fit. A inore narrowly drawn ordinance would impose architectural restraints, require parking lots, or provide for cleanup crews. The broader outright ban has a closer fit with the purely protectionist purpose.

153. See supra text accompanying note 151 .

154. See, e.g., Dean Milk Co. v. Madison, 340 U.S. 349, 353-56 (1951).

155. This approach does not, admittedly, solve all local political problems. Even a well-tailored nonprotectionist program may be supported by private interests who stand to reap anticompetitive benefit. Indeed, even municipal legislators may support proposed ordinances for such reasons. This problem may be inherently political and not well-suited to be remedied by the club of antitrust litigation. Furthermore, the proposed analysis, while not punishing all anticompetitive motivations, does prevent such motivations from being translated into predominantly protectionist legislation. 


\section{c. Localness}

In order for the municipality successfully to maintain that it, rather than the state, is the appropriate government unit to impose the challenged anticompetitive regulation, it must demonstrate that the regulation solves a purely local problem. As long as the city operates within its jurisdiction, it retams the legitimacy that justifies its balancing of social norms against competition. Regional problems demand solution by state or national governments; municipalities lose their governmental complexion by acting extraterritorially.

The locality requirement makes economic sense and comports with antitrust policies. Local problems are best, and perhaps necessarily, resolved by local governments. National and state legislatures may be too removed to recognize local problems. Local problems may be too numerous to be managed by larger governmental units. Resolution of local problems may generate political rewards only for a single representative in a multi-member state or national legislature. Entire local governing bodies may, in contrast, be answerable to those affected by local problems. Furthermore, local officials will generally have better knowledge of local conditions, and so will be better able to recognize problems and tailor solutions that minimize market disruptions. Resolving local problems locally will thus usually be more efficient. ${ }^{156}$ Moreover, this increase in efficiency may offset anticompetitive effects of the action. Thus, according to this analysis, the problem addressed by the challenged action must occur in a locally defined market. ${ }^{157}$

Tradition may play a legitimate role in determining whether a municipal action violates the locality principle. Many types of government action are so historically tied to local control that state government may be politically unable to implement them. While tradition may vary from state to state, possible examples include controlling land use, regulating public transportation, and improving infrastructure. ${ }^{158}$

156. See Brennan, supra note 11 , at 407-09.

157. Ascertaining the geographical boundaries of the relevant market is a standard determination in antitrust litigation. See generally L. SullivaN, supra note $38, \S 12$, at $41-44$, $\$ \$ 19-20$, at $67-70$. The determination of whether a problem is local or regional may often present difficulties. Many apparently local problems are likely to have regional causes or consequences, at least indirectly. In cases where the problem is regional but affects several local governmental divisions, this locality principle may require intergovernmental solutions to avoid antitrust liability. Nevertheless, the classification is one uniquely suited to antitrust litigation.

158. Many of these local activities arguably are outside the reach of the commerce clause. The reach of this extra protection is, however, uncertain and subject to change. The commerce clause powers have not stopped growing, and McClain v. Real Estate Bd., 444 U.S. 232 (1980), shows that the clause already reaches areas of traditional local concern. Furthermore, for cities near state boundaries, no activity may be local enough to avoid affecting interstate commerce.

The determination of whether a problem is local or regional may often present difficulties. Many apparently local problems are likely to have regional causes or consequences, at least indirectly. Nevertheless, the classification is one uniquely suited to antitrust litigation. 


\section{Solution Legitimacy}

If the city meets its initial burden by showing that the identified problem is an appropriate one for local government, the court should shift its analysis from the problem to the solution. The means chosen to resolve the problem must be consistent with the city's governmental legitimacy occasionally to displace competition with regulation. This Comment suggests that the key to such legitimacy is the relationship of the governmental decisionmaker to those who bear the resulting anticompetitive burdens and benefits. This approach can best be understood by examiming three possible benefit relationships-(1) where the local government benefits; (2) where the residents benefit at the expense of nonresidents; and (3) where both the benefits and the burdens are distributed among the residents.

\section{a. The Governmental Unit as Beneficiary}

When a city as an entity gains by its actions such as through increased revenue, it is employing anticompetitive restraints for self-gain, as a private entity would, instead of regulating directly to improve public welfare. While any economic gain to the city ultimately inures to its citizens, the benefit is usually indirect, weakening its public welfare justification for anticompetitive activity.

More importantly, a direct benefit for the city violates the self-interest factor suggested by City of Lafayette footnote forty-eight. ${ }^{159}$ When the governmental decisionmaker gains by its anticompetitive action, it loses the presumed neutrality that otherwise gives it the legitimacy to balance public welfare gains against harm to free competition. ${ }^{160}$ Absent that neutrality, a court has no basis to defer to the city's policy and must apply the rule of reason's strict criteria of effect on competition.

"Gain" is used here to mean benefit from displacing competition. A city's gain may take the form of monopoly rents or improved market position through the restriction or the elimination of competition. This model is most directly implicated when the city is a market participant. ${ }^{161}$ The tying arrangement implemented by the power plants in City of Lafayette ${ }^{162}$ illustrates a corollary to this requirement-that the competition stilled should not be that of the city's competitors. Another

159. City of Lafayette, 435 U.S. at 417 n.48 (plurality opinion); see supra pp. 1848-49.

160. City of Lafayette, 435 U.S. at 417 n.48 (plurality opinion). Despite the organization's public good character, self-interested restraints of trade are prohibited. Cf. Fashion Originators' Guild of America v. FTC, 312 U.S. 457, 467-68 (1941) (holding that the boycott of garment manufacturers who copy the designs of others is subject to Sherman Act prohibitions regardless of the boycott's reasonableness or the tortious nature of the design copiers).

161. See City of Lafayette, 435 U.S. at 418-26 (Burger, C.J., concurring).

162. For a more detailed discussion of the City of Lafayette facts, see infra text accompanying note 207. 
corollary is that a city may not use anticompetitive means to generate operating funds. ${ }^{163} \mathrm{~A}$ city may no more earn monopoly profits than may a private party. Thus if a mumicipality directly benefits from its action, it loses its governmental legitimacy and should be subject to the traditional rule of reason.

\section{b. Residents as Beneficiaries at the Expense of Nonresidents}

A city may not displace the burdens and benefits of competition for its own self-interest. Similarly, it may not benefit the economic interests of its residents at the expense of nonresidents. The city's governmental character would not, after all, distinguish it from a private antitrust violator in the eyes of the nonresidents. This perspective and its concern for nonresidents was a prime motivating factor for the City of Lafayette majority. ${ }^{164}$ Stated another way, a city may not advance its goals by imposing externalities. ${ }^{165}$

The externality problem also underlies the locality rule articulated above. ${ }^{166}$ If the problem motivating the anticompetitive regulation is nonlocal, locally imposed solutions are likely to work by displacing burdens rather than by ameliorating problems. Consider, as an example, the gasoline shortages of the 1970's, during which gasoline stations were open only a few hours a week with cars lined up for blocks waiting to purchase gasoline. If New York City had passed an ordinance requiring service stations to supply gasoline five days a week, this would violate the locality rule-the shortage was national. Such a solution would also create an externality by funnelling more supply to New Yorkers, thereby aggravating the shortage elsewhere. Instead, New York passed odd-even laws and half-tank laws. Cars with even-numbered license plates could purchase gas only on even days; odd-numbered cars could fill up only on odd days. No car could buy gasoline unless its tank was less than halffull. These laws responded to the local problem of gas lines and resolved the problem locally, without displacing burdens outside the city. ${ }^{167}$

163. Revenues may be raised via taxation or through revenue sharing with the state or federal government. While taxation inevitably exerts its oivn biases on market decisions, its burdens arc spread quite widely, and thus it would seem to result in less market distortion than anticompetitive market participation.

164. City of Lafayette, 435 U.S. at 403-05.

165. An externality is a burden or benefit imposed by an activity on an unwilling nonparticipant. For a discussion of externalities, such as pollution, that may constitute market failure, see Cirace, supra note 123 , at $493-94$.

The analysis in this Comment uses the externality concept as a limitation on municipal power to displace competition. While agreeing with commentators such as Cirace, supra note 123, that market failures caused by externalities generally justify regulation, it asserts that existing externalities do not justify retaliatory externalities by the burdened municipality.

166. See supra pp. 1856-57.

167. The five-day requirement would thus fail two prongs of the proposed analysis-it would be a response to a nonlocal market failure (national supply shortage), as well as a resolution via 
This mode of analysis derives from the representation factor suggested by City of Lafayette footnote forty-eight. The anticompetitive complexion of a government action is lessened when the complainant is a citizen of the municipality. ${ }^{168}$ When the complainant has no voice in the defendant's decisionmaking, however, this mitigating factor is absent. Thus, when a city solves a local problem by displacing anticompetitive burdens outside the city, the burdened nonresidents should be entitled to the protection of rule of reason analysis. The city should not be permitted to justify its action by citing the resulting benefits enjoyed by its citizens.

\section{c. Internal Redistribution of Competitive Burdens and Benefits}

This paradigm presents the strongest case for judicial deference to municipal action. According to the representation factor, the economic power consolidated by the defendant government is shared by the residents of the jurisdiction, including any resident complainant. Any burden borne by the complainant is not that caused by an external competitor, but by a decisionmaking process in which the complainant is represented.

The anticompetitive complexion of the burden is not only mitigated; it is transformed into a political complexion. The complainant suffers the injury of one who was politically unable to prevail in an internal decisionmaking process. Every municipal regulation disadvantages some people; the disadvantage acquires no special significance merely because it takes the form of an antitrust injury. When the burdened municipal residents have access to the political machinery, municipal anticompetitive regulation is not qualitatively different from state anticompetitive regulation. Furthermore, if the burden is internalized, direct harm to interstate commerce is minimized. ${ }^{169}$

Internal displacement of anticompetitive burdens and benefits carries two related risks. First, a political majority may use the political process to achieve wealth transfer from a minority. Additionally, private parties may use the city machinery to achieve gains from competitors.

externalization. The locality rule and analysis in terms of externalities are not always redundant. Assume that the city of San Francisco decided that automobile traffic from neighboring Marin County was polluting its air. San Francisco certainly could not institute tolls on cars registered in Marin using the Golden Gate Bridge in order to generate funds to reduce pollution generated in San Francisco. The pollution problem is local, but the proposed solution would burden nonresidents only. Thus, the toll would pass the locality rule, but fail the externalities prohibition.

168. See supra pp. 1849-50.

169. A burden may affect interstate commerce for jurisdictional purposes without creating antitrust injury in interstate commerce. Compare McClain v. Real Estate Bd., 444 U.S. 232 (1980) (extensive tracing of antitrust injury for purposes of satisfying jurisdictional requirement of effect on interstate commerce), with Hanover Shoe, Inc. v. United Shoe Machinery Corp., 392 U.S. 481 (1968) (limiting tracing of antitrust injury for substantive purposes). 
These problems are better dealt with outside the antitrust arena. ${ }^{170}$ For example, protection from majority rule is generally provided by federal statutes and the Constitution. Remedies against private abuse by local government are generally provided by anticorruption statutes, state doctrines of ultra vires, and state statutory and constitutional limits on municipal governments. ${ }^{171}$ Absent such particular causes of action, however, federal courts should generally accord the traditional deference to the legitimacy of local processes for balancing internal competing interests. ${ }^{172}$

Antitrust doctrine can, however, implement the fair procedures factor by providing two relatively simple ways to limit private economic power achieved through politically-implemented restraints on competition. First, this Comment's analysis, ${ }^{173}$ although refraining from examining municipal procedures, ${ }^{174}$ requires the city to demonstrate that it is acting to rectify a nonprotectionist problem. If the plaintiff proves that the city's goal was to aid a private party rather than to serve the public welfare, the city will be subject to standard antitrust analysis without consideration for its governmental status. ${ }^{175}$

The second limitation is a corollary of the Parker $v$. Brown case relating to state actions. Parker itself warned that a government may not immunize private anticompetitive behavior. ${ }^{176}$ Later cases have developed the doctrine of "active supervision." 177 When the private entity administering the state's anticompetitive program has discretionary authority, it must be subject to the state's active supervision. For example, where a state enforced private resale price schedules, Parker immunity was inapplicable because " $t$ ] $]$ he state neither establishe[d] prices nor review[ed] the reasonableness of the price schedules." 178 No less can be required of a city. ${ }^{179} \mathrm{~A}$ city may not delegate anticompetitive regulation to a private body or to one of its governmental subunits without exercis-

170. Brennan, supra note 11 , at 432 .

171. See supra note 127. When such protections fail, residents who are excluded from political coalitions have two other sources of protection. First, the proposed analysis protects them from specifically anticompetitive actions. Second, all residents have the political remedy of creating new coalitions and replacing incumbent officials.

172. Many of the early post-City of Lafayette cases were responses to corruption rather than true anticompetitive governmental action. See supra note 59. By confusing the two issues, the courts created a particularly standardless inquiry.

173. See supra pp. 1851-52.

174. See supra pp. 1846-48.

175. See supra pp. $1855-56$.

176. Parker v. Brown, 317 U.S. 341,351 (1943).

177. See, e.g, California Retail Liquor Dealers Ass'n v. Midcal Aluminum, Inc., 445 U.S. 97, 105 (1980) (quoting City of Lafayette v. Louisiana Power \& Light Co., 435 U.S. 389, 410 (1978) (plurality opinion)).

178. Id.. The Midcal Aluminum Court also observed that "[t]he State does not monitor market conditions or engage in any pointed reexamination of the program." Id. at 106 (footnote omitted).

179. Note, however, that the Midcal Aluminum requirement, $i d$. at 105 , served the doctrinal 
ing supervisory authority. ${ }^{180}$ This requirement further adds to a city's legitimacy, in accordance with the fair procedures requirement, by serving as an administrable surrogate for an inquiry into a city's lawmaking processes.

A difficult question arises as to who is a nonresident for purposes of determining whether the challenged action has a governmental complexion by virtue of internalization. The distinction between voters and nonvoters is an obvious beginning. The ability to vote defines who is, and who is not, a part of the decisionmaking body. Participation is the critical variable. A more careful inquiry into the democratic process reveals, however, that voting rights are not necessarily the most important indicator of influence. Nonvoting landowners or business proprietors may have great influence in local government. It may be inaccurate to characterize governmental action against them as equivalent to that of an unrelated competitor. They might more appropriately be viewed as losers in a political battle in which they fully participate. Furthermore, their input may be ongoing, and they may attam reversals of position, or prevail in other disputes. While a detailed analysis of local political power would be a cumbersome addition to antitrust litigation, courts could identify situations in which burdens on a nonresident should count as internal redistribution rather than as an externality. Landowners will generally fall in this category, and guidelines should be developed as to when locally run but externally owned businesses should also be so treated. ${ }^{181}$

\section{Solution Effectiveness}

The first two prongs of the proposed analysis establish factors that identify whether a municipality's actions take on a nonanticompetitive "complexion." An anticompetitive ordinance which meets the standards

role of a prerequisite to immunity. This Comment's analysis uses it as a factor in determining liability.

180. Other Parker limitations should not carry over to the municipal defendant setting. Although applicable in principle they are not suited to the practicalities of local government. The other prong of the Midcal Aluminum test, for example, is that the challenged restraint be " "clcarly articulated and affirmatively expressed as state policy." "Id. (quoting City of Lafayette v. Louisiana Power \& Light Co., 435 U.S. 389, 410 (1978) (plurality opinion)). The purpose of this requirement is similar to the active supervision requirement-it ensures the challenged activity is governmental policy rather than immunized private behavior. But the informal procedures of local governments preclude imposing any articulation requirement upon them.

Similarly, the Court has suggested that the restraint must be part of a "comprehensive regulatory system." See, e.g., City of Lafayette, 435 U.S. at 410 (1978) (plurality opinion). This requirement helps limit immunity to those actions which are truly governmental in nature. The requirement is inappropriate to local government liability, however, because much of the local governmental action is of necessity situation-specific rather than regulatory in nature.

181. Cf. Rose, supra note 122, at 883-87 (factors which legitimate local government are opportunities to be heard ("voice") and limited opportunities to leave ("exit")). 
suggested would not produce the sort of anticompetitive profits the Sherman Act was enacted to prevent. The ordinance would have what this Comment calls "governmental nonliability." Few anticompetitive municipal actions will have the purity required above, however. Most actions will deal with problems that extend beyond city borders and will create some externalities. Such imperfections should not remove all governmental legitimacy from the action and immediately trigger traditional private party analysis. The external anticompetitive effects, or self-interested nature of the regulation must, however, weigh in favor of liability. The remaining question is what to place on the other side of the balance.

The last prong of the proposed analysis attempts a compromise between two unpleasant alternatives. The first approach would use the standard rule of reason analysis utilized in National Society of Professional Engineers $v$. United States ${ }^{182}$ to weigh the anticompetitive effects against the procompetitive gains. ${ }^{183}$ The second approach would directly weigh the anticompetitive effects against the social welfare benefits. ${ }^{184}$ The former approach fails to take into account the defendant's public welfare responsibilities. The latter alternative would throw the courts into a standardless substantive due process analysis. While some level of judicial policymaking may perhaps be unavoidable, it can be kept in check by focusing the analysis on the effectiveness of the solution. In this last line of inquiry, therefore, a court should evaluate the extent to which the challenged activity achieves the city's asserted goal and the extent to which it minimizes external anticompetitive effects. While this inquiry may take many forms, two themes should be stressed-the solution should fit the problem, and externalization of burdens should be disfavored.

\section{a. The Action Should Be Narrowly Tailored to the Problem}

The solution should impose the fewest restraints necessary to rectify

182. 435 U.S. $679,686-96$ (1978).

183. For the purposes of this subsection, "anticompetitive effects" means both external displaced competitive burdens, see supra pp. 1859-59., and municipal competitive gain, see supra pp. 1857-58. To the extent anticompetitive harms representing democratic internal redistribution can be identified and segregated, they should be excluded from the balance.

This alternative has received little support, although Justice Lucas of the California Supreme Court comes close to endorsing it in his dissent in Fisher v. City of Berkeley, in which he urges application of the per se rule against Berkeley's rent control ordinance. $37 \mathrm{Cal}$. 3d 644, 717, 693 P.2d 261, 317, 209 Cal. Rptr. 682, 738 (1984) (Lucas, J., dissenting), prob. juris, noted, 105 S. Ct. 2653 (1985) (No. 84-1538).

184. This approach was originally suggested as a modification of state immunity. See Slater, supra note 86, at 104-08; see also Posner, supra note 72, at 712-14 (as applied to health and safety regulation). It has more recently been recommended as the solution to the municipal liability dilemma. See, e.g., Comment, supra note 38, at 816-18 (proposing balancing test for nonproprietary activities of local governments); Note, The Preemption Alternative to Municipal Antitrust Liability, 51 GEO. WASH. L. REV. 145, 165-66 (same). 
the problem. As a minimum, the challenged municipal action should preserve avenues for market self-correction. One way to do this is with what is known as a "sunset provision." If the problem to which the challenged action is addressed is not necessarily permanent, the enacted solution should terminate of its own accord, either at a pre-set date, or when the problem abates. Rent control statutes, for example, often terminate by their own terms when the apartment vacancy rate climbs to a predetermined level. ${ }^{185}$

Other creative ways of preserving market self-correction may be built into anticompetitive measures. For example, where a city's demographics are such that a single cable TV supplier saturates the market, the city may justify regulation of the cable market by recoguizing the natural monopoly. ${ }^{186}$ It should nevertheless use a cable infrastructure that facilitates entry of a competitor in case the market or the economics change.

Another way for a court to ensure that a challenged regulation minimizes anticompetitive restramts is to consider the goals of antitrust law. Relevant antitrust goals include having unany economic actors, low entry barriers, responsiveness of supply markets, and absence of monopoly profits. The challenged action should interfere with as few goals as possible. For exainple, suppose a city limits the number of food concessions at its airport, thereby limiting the ability of the supply inarket to respond to demand. It might mitigate this anticompetitive effect by requiring that each concession be independently owned, thereby promoting the goal of multiple economic actors.

\section{b. Externalities Should Be Minimized}

To the extent the anticompetitive burdens of the challenged action are irreducible, they should be placed on those who have a representative voice in the decisionmaking process. This can be accomplished in two ways-channelhing the burden, and giving voice to those bearing the burden.

i. Burden placement. Where possible, burdens should be placed on parties to whom the city is politically responsible. Indeed, the city should internalize even if such internalization results in somewhat higher burdens or inefficiency.

185. See, e.g., Rent Control Law of Santa Monica, art. XVIII § 1803(r) (rent control board authorized to remove rent control if vacancy rate exceeds 5\%), cited in J. GILDERBLOOM, RENT Control: A SOURCE Book 303, 309 (1981); Berkeley Rent Stabilization and Eviction for Good Cause Ordinance $\S 6(q)$ (mcans of ending rent control if vacancy rate exceeds $5 \%$ ), cited in Fisher $v$. City of Berkeley, 37 Cal. 3d 644, 668, 693 P.2d 261, 282, 209 Cal. Rptr. 682, 702 (1984), prob. juris. noted, 105 S. Ct. 2653 (1985) (No. 84-1538); J. GILDERBLOOM, supra, at 115 (suggesting that decontrol after fixed time or when vacancy rate rises is "typical").

186. See infra text accompanying note 220 . 
For example, suppose a city seeks to procure private bus service for its three main avenues. Since unbridled competition could produce unstable schedules, unreliable service, and rider confusion as well as make operations unprofitable for the providers, the city plans to sell exclusive licenses for bus service. It must choose between selling one license for the entire city or selling three separate licenses for the three proposed lines. The first alternative might produce economies of scale for the single licensee, resulting in reduced fares for city residents. But it also forecloses competition among licensees and reduces by a factor of three opportumities for private companies to exploit the market. The unitary license produces benefits to city residents and imposes burdens externally. The multiple license alternative internalizes some of the burden. Although private bus companies are still greatly limited in their ability to compete, they have three times the opportunity to enter the market. Residents absorb some of the burden by paying higher fares to compensate the providers for any reduced efficiencies. While the threelicense alternative is not mandatory under the proposed analysis, it illustrates that internatization of anticompetitive burdens would be possible. Employing an internalization alternative would weigh against antitrust liability.

ii. Avenues for redress. When burdens must be placed outside the city, the city should find ways to give those affected a voice in the decisionmaking process. For example, intergovernmental districts may be set up to distribute services or to create a unitary transportation system so that otherwise burdened outsiders could participate in and share the benefits of the regulatory scheme.

\section{Evaluation of the Analysis}

Numerous commentators and courts have suggested methods of analysis of municipal antitrust liability. ${ }^{187}$ The proposed analyses fall into two categories. The first set excuses local governmental actors from liability if they comply with one or more of the following three requirements: the action is a legitimate exercise of local power; the act was authorized using fair procedures; the action accomplishes its goal with minimized anticompetitive effects. ${ }^{188}$ The second set of suggested analy-

187. See, e.g., proposals discussed infra at notes $188,189 \& 198$.

188. See, e.g., Fisher v. City of Berkeley, 37 Cal. 3d 644, 675-77, 693 P.2d 261, 286-87, 209 Cal. Rptr. 682, 707-08 (1984) (no liability if regulation has proper local purpose, operates evenhandedly, and purpose could not be achieved as effectively with less harm to antitrust policies), prob. juris. noted, 105 S. Ct. 2653 (1985) (No. 84-1538); Cirace, supra note 123, at 497-98 (nonliability dependent upon, among other things, procedural due process, ethical conduct, and exemptions being no broader than necessary to accomplish their purpose); Note, The Application of Antitrust Laws to Municipal Activities, 79 Colum. L. REv. 518, 539-41 (1979) (no liability if municipality has legitimate purpose that could not be furthered as effectively through competitive means and the means substantially furthered the purpose). 
ses directs courts to find nonliability if the city's public purposes outweigh the action's anticompetitive effects. ${ }^{189}$ This Comment argues that these methods of analysis, although plausible in theory, are inconsistent with Supreme Court precedent and unworkable under current law. This section identifies five criteria for a more realistic analysis. It goes on to demonstrate how the proposed analysis satisfies these criteria. The accompanying footnotes explain where some previously proposed analyses fall short.

First, to be of use to lower courts, the analysis must be consistent with the three-level system the Supreme Court has imposed. Private parties should have the greatest exposure, cities without Parker immunity should have less exposure than private parties, and states (and cities with delegated authority under City of Boulder) should be immune. Commentators have made strong arguments that Parker overprotects states, ${ }^{190}$ that City of Lafayette and City of Boulder underprotect cities, ${ }^{191}$ and that states and cities should be treated alike ${ }^{192}$ since the economic effects of municipal and of state regulation are similar. ${ }^{193}$ The Supreme Court, however, has shown no inclination to alter the state action doctrinal structure. ${ }^{194}$ A practical analysis must therefore take this three-level structure for granted.

The proposed analysis satisfies this criterion. It is faithful to Supreme Court precedent by distimguishing local governments fron both private parties and state governments, and by directing litigation to the

189. See, e.g., commentators cited supra note 184; see also Fisher v. City of Berkeley, 37 Cal. $3 \mathrm{~d}$ 644, 674 n.25, 693 P.2d 261, 285 n.25, 209 Cal. Rptr. 682, 706 n.25 (1984) (criticizing such an approach and citing examples), prob. juris. noted, 105 S. Ct. 2653 (1985) (No. 94-1538).

190. See, e.g., Posner, supra note 72; Slater, supra note 86. A strong criticism of Parker centers around its inconsistency with federal preemption doctrine. Normally, any federal statute displaces inconsistent state or local regulation. It is ironic that the antitrust laws, which are almost constitutional in stature, carry less preemptive weight than other statutes. Criticism of Parker has increased with the spate of Supreme Court decisions concerning it, see, e.g., Posner, supra note 72; Slater, supra note 86 , and some commentators have used the municipal liability problem as a vehicle to attack the Parker doctrine. See, e.g., Cirace, supra note 123, at 498-99 (proposing exemption narrower than that provided by the Parker doctrine for both states and municipalities).

A chief justification for Parker is necessity. Given the breadth and scope of the Sherman Act, little governmental activity would survive antitrust challenge absent some immunity. Fisher, $37 \mathrm{Cal}$. 3d at 678, 693 P.2d at 284, 209 Cal. Rptr. at 705; Posner, supra note 72, at 697.

191. See, e.g., Cirace, supra note 123, at 490 ; Note, supra note 188 , at 539.

192. In other contexts, federalism analysis does not distinguish between states and local governments. The eleventh amendment's reserve powers inure equally to states and their subdivisions, National League of Cities v. Usery, 426 U.S. 833, 855 n.20 (1976), overruled on other grounds, Garcia v. San Antonio Metropolitan Transit Auth., 105 S. Ct. 1005 (1985). Similarly, in preemption analysis, inconsistent state laws are viewed with no less disfavor than inconsistent municipal ordinances. Burbank v. Lockheed Air Terminal, Inc., 411 U.S. 624 (1973).

193. Cirace, supra note 123.

194. Indeed, a decade of the Court's attention, see supra note 25 , has produced a reasonably well-defined doctrinal structure. 
quality that makes local governments distinct--their ability to regulate local problems.

Second, the analysis should take account of cities' public welfare responsibilities. As discussed above, ${ }^{195}$ if anticompetitive self-regulation by any party can be justified, it should be in the context of governmental action. Although the Court is apparently firmly committed to its decision to restrict some municipal actions on antitrust grounds, it presumably did not intend to eviscerate the municipal power to promote social welfare. Neither City of Lafayette nor City of Boulder speaks of such a total restructuring of American government. Any new analysis must therefore preserve the ability of local governments to resolve most local problems autonomously.

The proposed analysis accords respect to localities' responsibilities for public welfare. It allows cities to respond to local problems through anticompetitive regulation without externalities, or, if externalities are unavoidable, by using a method which minimizes externalized anticompetitive burdens. Furthermore, the proposed analysis maximizes local autonomy by deferring to defendant municipalities' choice of objectives. A city must identify why it is dissatisfied with the free market. ${ }^{196}$ At the same time, the city has leeway to define any social policy norms it chooses, as long as the norms do not directly oppose the national goal of free competition. ${ }^{197}$ This requires the city to conform to the concepts of antitrust doctrime, but allows it the autonomy to define its social and economic goals and policies. ${ }^{198}$

Third, an acceptable analysis must speak the language and promote the goals of the antitrust laws. City of Lafayette exposed municipalities to antitrust liability because they could pose the very dangers to competition that the antitrust laws are supposed to eliminate. Footnote fortyeight, the Court's minimalist word on the subject, is framed in terms of anticompetitiveness. Any analysis must highlight and evaluate the burdens imposed on the free market economy. ${ }^{199}$

195. See supra Part II, Section $B$.

196. See supra pp. 1852-55.

197. See supra Part II, Section $B$.

198. Most commentators have responded to the goal of preserving local power and autonomy with greater leniency than proposed here. Some commentators have recommended a straightforward "broad rule of reason" which would allow municipal defendants to advance public benefit justifieations and then leave it to the courts to balance anticompetitive harms with social good. See supra note 184. Others have gone so far as to urge a "good government" that would provide immunity for reasonably necessary public welfare regulation. See, e.g., James, supra note 14, at 294. While these proposals satisfy criterion two, they fail to respect the criteria discussed below, in particular criterion three (respecting antitrust policy) and criterion five (limiting judicial discretion).

199. Courts and commentators responding to City of Lafayette and City of Boulder have structured shields for local governments, ranging from simple good government exceptions to more complex analyses modeled after constitutional law. Most of these analyses, however, focus heavily 
The proposed analysis articulates and promotes antitrust goals. Instead of shielding well-intentioned municipalities, it directs a court's attention to the economics of the defendant's activity. By focusing on the loci of burdens and benefits, it requires identification and economic analysis of the anticompetitive effects of the challenged activity.

Fourth, an effective analysis must reconcile the conflicting goals of minimizing the anticompetitive burden on interstate commerce and maximizing local autonomy. Analysis which intrinsically favors one over the other fails in its essential purpose ${ }^{200}$ and analysis which inhibits one goal without advancing the other is mefficient. The ideal analysis maximizes, in some sense, both goals. A trial court should not engage in a "balancing test" between local policy goals and the anticompetitive burden ${ }^{201}$ because such balancing raises the dangers of the Lochner era: balancing tests provide no analytic guidance and force policy choices outside the sphere of judicial competence. Nevertheless, any proposed method of analysis should itself be evaluated on how well it achieves both policy objectives.

The proposed analysis indeed maximizes the two goals of free competition and local autonomy. The degree of deference accorded each goal depends on the specific fact situation. Where local problems are met by local solutions, mumcipal policies take priority. But where anticompetitive effects have an impact on nonparticipatory outsiders, antitrust goals come to the fore.

Fifth, any practical methodology should avoid the evils of substantive due process analysis; it should not allow courts to evaluate the merits of the cities' goals. ${ }^{202}$ While any analysis must resolve conflicts between antitrust policy and social welfare legislation, it should avoid assessing the value of the city's policies. ${ }^{203}$

on the governmental character of the challenged action, and give little attention to effect on competition. Fisher v. City of Berkeley, 37 Cal. 3d 644, 693 P.2d 261, 209 Cal. Rptr. 682 (1984), prob. juris. noted, $105 \mathrm{~S}$. Ct. 2653 (1985) (No. 84-1538), is the least offensive of these, but nevertheless, only the dissent has a brief paragraph discussing how alternative solutions to the city's problems affect competition. Fisher, $37 \mathrm{Cal}$. 3d at 718, 693 P.2d at 318, 209 Cal. Rptr. at 739 (Lucas, J. dissenting).

200. Consider the analysis in Fisher v. City of Berkeley, 37 Cal. 3d 644, 693 P.2d 261, 209 Cal. Rptr. 682 (1984), prob. juris. noted, 105 S. Ct. 2653 (1985) (No. 84-1538), for example, which permits a loophole for plaintiffs if defendants prevail on the good government defense. The regulation may be denied effect if "the city's purposes could be achieved as effectively by means that would have a less intrnsive impact on federal antitrust policies." Fisher, $37 \mathrm{Cal}$. 3d at 675, 693 P.2d at 287,209 Cal. Rptr. at 707-08. In conflict between free competition and other goals, the standard appears to favor welfare goals. Thus, in cases in which the challenged activity achieves modest public welfare goals only at the cost of significant anticompetitive harm, the activity would likely be upheld.

201. Although the proposed analysis does not entirely eliminate balancing tests, it substantially limits them. See infra text accompanying note 204.

202. Cirace, supra note 123 , at 484 , declares that courts have been using substantive due process in most state action cases.

203. This is another danger of the "broad rule of reason" analysis. It requires courts to balance 
The proposed analysis strives to avoid judicial policymaking. In many cases a balancing of antitrust goals against the municipality's goals will be unnecessary. The former will be disregarded when burdens are fully internalized and the latter will be disregarded when no nonanticompetitive local problem is demonstrated. Even when balancing is inevitable, the analysis provides structure for the decision. It evaluates the strength of the antitrust policies based on governmental representation of the complainant and the ratio of external to internal net economic burden. It evaluates the strength of the challenged activity's goals in terms of their effectiveness rather than their merit. ${ }^{204}$

\section{IV \\ APPLICATION OF THE ANALYSIS}

The virtues and weaknesses of the proposed analysis as a means of deciding litigation can best be illustrated with examples. This Comment will now explore low the analysis would function as applied to some recent cases on municipal antitrust liability. ${ }^{205}$ Three broad categories of

anticompetitive harm against the municipal activity, but provides no analytic guides for the inevitable policy choice.

204. The California Supreme Court is the only appellate court to have developed a method of analysis of municipal antitrust liability. Fisher v. City of Berkeley, 37 Cal. 3d 644, 693 P.2d 261, 209 Cal. Rptr. 682 (1984), prob. juris. noted, 105 S. Ct. 2653 (1985) (No. 84-1538). The court in Fisher adopted the following test for municipal antitrust liability:

[I]f a municipal regulation has a proper local purpose, is rationally related to the municipality's legitimate exercise of its police power, and operates in an even handed manner, it must be upheld against a claim that it conflicts with section 1 of the Sherman Act unless the plaintiff demonstrates that the city's purposes could be achieved as effectively by means that would have a less intrusive impact on federal antitrust policies.

Fisher, $37 \mathrm{Cal}$. 3d at 675, 693 P.2d at 286-87, 209 Cal. Rptr. at 707-08 (footnotes omitted). In effect, the court provided a "good government" shield for municipalities, subject only to a "less restrictive alternative" test derived from the U.S. Supreme Court's commerce clause cases.

The problem with this approach is twofold. First, it permits local governments to enact statutes with grossly anticompetitive effects on the national economy for any "proper" local purpose so long as the statute is well-crafted. Instead of compromising between the goal of free competition and local autonomy, it is inherently biased in favor of the latter. Second, the less intrusive alternative approach is highly subjective and permits great judicial discretion.

The proposed analysis, in contrast, would limit "good government" justifications primarily to anticompetitive displacements within the government's jurisdiction. Any significant externalities would be subject to traditional rule of reason analysis. See supra text following note 168 . The least anticompetitive alternative analysis, although permitting some jndicial discretion, contains some guidelines and would be restricted. It is limited to situations in which the city has limited selfinterest or where external anticompetitive effects are small compared to internal competitive redistribution.

205. Many of the decisions have resulted in immunity for the defendants based on City of Boulder. The analysis of this comment suggests that these cases represent overly liberal interpretations of City of Boulder, stemming partially from what many perceived as a tenuous majority, and in part from the desire to protect municipalities from treble damages. With the consolidation of the Court around the City of Boulder rule in the unanimous Town of Hallie v. City of Eau Claire, $105 \mathrm{~S}$. Ct. 1713 (1985), and the abrogation of treble damages for local governments in the Local Government Antitrust Act of 1984, Pub. L. No. 98-544, 98 Stat. 2750 (codified at 15 
cases are identified. In the first, municipalities acting as market participants were accused of fairly traditional antitrust violations. In the second and larger group of cases, the local government appeared to have been "captured" by private interests, and acted to protect those interests from competition. In the third group, cities determined that natural monopolies required displacing competition from a segment of the economy and replacing it with a monopolized provider. This Comment will examine the three groups of cases and apply the proposed analysis; it will then focus on a more particular issue now being litigated-the challenge to rent control ordinances.

\section{A. Municipality as Market Participant}

When a municipality participates in the market by operating a business, it inay run afoul of the antitrust laws. This is the paradigm case in which municipal antitrust liability should be imposed. ${ }^{206}$ Because the municipality is generally acting in its financial self-interest, its motives and conduct are that of a private party and are not entitled to the deference accorded a governmental regulatory decision.

The proposed analysis would generally treat cities as private parties when they are challenged in a market participant capacity. In many such cases, the municipality will fail the first prong of the analysis: it will be unable to prove a local nonanticompetitive goal because its motive will have been to improve its market position rather than to remedy a local problem.

The governmental defendants in City of Lafayette fall into this category. City of Lafayette arose out of antitrust litigation between a private electric utility company and several cities which owned and operated competing utility systems. Both sides alleged antitrust violations by the other. The causes of action against the city included tying, refusal to wheel power, boycotting, and sham litigation. ${ }^{207}$ It is unlikely such conduct could have been justified with nonprotectionist public welfare arguments. Furthermore, in at least one count, the challenged municipal conduct was directed at consumers outside city limits. ${ }^{208}$ It is unlikely the city could have explained this as a response to a local problem. Absent a local problem qualifying under the initial inquiry, the city has no legitimate reason to be treated as a government regulator.

U.S.C. $\S \S 34-36$ (Supp. II 1984)), courts may be increasingly willing to deny immunity and reach issues of liability. In the meantime, the facts of those cases provide suitable case studies.

206. Indeed, it was as market participants that municipalities were first exposed to antitrust liability. Chief Justice Burger's concurrence so limited the City of Lafayette plurality in 1978. 435 U.S. at 418 (Burger, C.J., concurring).

207. Id. at 392 n.5.

208. See City of Lafayette v. Louisiana Power \& Light Co., 532 F.2d 431, 432-33 (5th Cir. 1976), affd, 435 U.S. 389 (1978). 
Even when a market-participant city passes the first prong by pointing to a facially legitimate goal, the second prong will forbid it from using anticompetitive means to generate operating revenues. A selfinterested action is not accorded governmental complexion. ${ }^{209}$ In two recent cases, appellate courts allowed antitrust challenges to market-participant municipal actions to proceed. ${ }^{210}$ In one, the defendant city was challenged for requiring its tenant retail stores to increase prices in parallel. ${ }^{211}$ In the other, the defendant city was sued for trying to extend its intrinsic municipal monopoly over zoning into the commercial monopoly of geothermal heating. ${ }^{212}$ The proposed analysis would treat each of these municipal defendants as a private party because its actions were designed to increase revenues.

This prong does not require private-party treatment whenever a city receives revenues from the business activity underlying the challenged action. The court must determine whether the action is self-interestedwhether revenues are increased as a result of the action. When Dallas and Fort Worth gave a taxicab company an exclusive franchise at their airport, for example, the fact that they received a percentage of the profits put thein in the self-interested category. The franchisee's monopoly, and its corresponding high profits, enriched municipal coffers. ${ }^{213}$ If, however, the cities had regulated fares or received a fixed price unrelated to the franchisee's profit level per cab ride, their revenues would not have been affected by the fact of monopolization, and they would have passed the self-interest test.

\section{B. Private Purpose}

Antitrust suits have recently been brought against cities where private parties have "captured" a local government and turned its mechanisins to private advantage. On the one hand, antitrust doctrine is not well suited to dealing with the seizure-of-power facet of these cases. Other federal and state causes of action are better tailored to reniedying unfair treatinent by government. On the other hand, the substance of the wrong committed often sounds in antitrust. In some of these cases, the city is facilitating a traditional private antitrust conspiracy. In Affiliated

209. See supra pp. pp. 1857-58.

210. The trial court proceedings on remand, which presumably deal with the issue of municipal liability, have not been published.

211. Kurek v. Pleasure Driveway \& Park Dist., 557 F.2d 580 (7th Cir. 1977), vacated and remanded in light of City of Lafayette, 435 U.S. 992 (1978), reinstated as to antitrust issues, 583 F.2d 378 (7th Cir. 1978), cert. denied, 439 U.S. 1090 (1979).

212. See Parks v. Watson, 716 F.2d 646 (9th Cir. 1983), in which the city tied a zoning variance to a geothermal well, requiring a developer to cede the well to the city as a condition to granting the former.

213. Woolen v. Surtran Taxicabs, Inc., 461 F. Supp. 1025 (N.D. Tex. 1978). 
Capital Corp. v. City of Houston, ${ }^{214}$ for example, Houston legitimized a territorial division conspiracy among cable TV operators. This was accompanied by a boycott of outside cable suppliers. In other cases, cities have enacted discriminatory regulations against one business to help a single competitor. These often take the form of downzoning potential developers, ${ }^{215}$ but more creative use of government machinery has also been used to eliminate competition. ${ }^{216}$ The common thread in these cases is that the local government is the means by which an essentially private restraint on competition is implemented.

In such cases, the city is not acting for governinental purposes, and should be treated as a private defendant. Under the proposed analysis, these governinental defendants would be denied any special consideration. In the initial inquiry, the city would most likely be unable to articulate a plausible nonprotectionist public purpose for its actions. Even if it could, the plaintiff could continue to challenge the city's purported public purpose. Under the identification component of the proposed analysis' first inquiry, the plaintiff may rebut the city's allegation of a nonanticompetitive goal by showing that the true purpose of the challenged action was private gain from stilling competition. ${ }^{217}$

If the city prevails under the first inquiry, the plaintiff would have to characterize the activity as one which falls into either of the two categories that result in liability. The plaintiff could show either that the city itself profits by its actions, or that the anticompetitive burdens are externalized because the plaintiff is outside the city and suffers injury. If

214. 735 F.2d 1555 (5th Cir. 1984) (en banc).

215. In Westborough Mall v. City of Cape Girardeau, 693 F.2d 733 (8th Cir. 1982), cert. denied, 461 U.S. 945 (1983), for example, the private parties were both developing shopping malls. The city downzoned plaintiff's land, forcing him out of his project, while simultaneously upzoning his competitor's land. In Schiessle v. Stephens, 525 F. Supp. 763 (N.D. Ill. 1981), the plaintiff alleged that the city was condemning her land in order to convey it to her competitors; see also Whitworth v. Perkins, 559 F.2d 378 (5th Cir. 1977), vacated and remanded in light of City of Lafayette sub nom. City of Impact v. Whitworth, 435 U.S. 992 (1978), reinstated, 576 F.2d 696 (5th Cir. 1978), cert. denied, 440 U.S. 911 (1979). In Whitworth, the plaintiff was denied a zoning variance to allow him to sell alcohol. The plaintiff alleged that the denial was part of a conspiracy by city officials and others with whom he would be in potential competition. Whitworth, 559 F.2d at 380.

216. In Corey v. Look, 641 F.2d 32 (1st Cir. 1981), the plaintiff, a parking lot operator, was forbidden by his permit to advertise or to charge parking fees other than on weekend evenings. The city made public school lots available free of charge to his competitor, and refused to aid plaintiff when his competitor used his lot without permission. In Omni Outdoor Advertising, Inc., v. Columbia Outdoor Advertising, Inc., 566 F. Supp. 1444 (D.S.C. 1983), Columbia, South Carolina, enacted an ordinance restricting construction of billboards when a local company owning $95 \%$ of the city's billboards was threatened by a competitor. The county enacted an ordinance allegedly harming the plaintiff while benefiting the incumbent. In Guthrie v. Genesee County, $494 \mathrm{~F}$. Supp. 950 (W.D.N.Y. 1980), plaintiff air charter operators were forced out of the county airport when the county discriminatorily denied them storage space for their tools and "client information" space in the terminal, and tripled the rent for their hangar space.

217. See supra pp. 1855-56. 
plaintiff makes a strong showing on either theory, the city would be treated as a private party and be judged under the rule of reason. If plaintiff makes a partial showing, the litigation would proceed to the third inquiry.

Under the third inquiry, the city would be forced to defend the effectiveness of its activities. The government actions at issue here often target a single coinpetitor. They are unlikely to be upheld under the third inquiry's requirement of inimimizing anticolnpetitive harm; such actions are intrinsically anticompetitive. Generally, the governmental goals established in the first prong will be equally attainable with ineasures that are nondiscriminatory and hence less anticompetitive.

\section{Natural Monopolies}

A more difficult problem arises when the defendant inunicipality alleges that its activities are necessitated by a natural monopoly. The defendant will satisfy the first inquiry by proving the existence of a natural monopoly or, in other words, that the inefficiency of a competitive market relative to a monopolized market makes the former nonsustainable. ${ }^{218}$

If a number of competitors are selling a product or service that a single proprietor could sell more efficiently, the market will evolve in one of three ways. First, the price may stabilize at an artificially high level to pay for the inefficiencies. Second, the competitors might drive each other out of business, depriving the consumers of the product or service entirely. Finally, competitive wars might culminate in a single surviving company. This last eventuality would create the power-accumulation dangers of an unregulated monopoly, as well as the risk of further instability should new entrepreneurs enter the market. By creating a regulated monopoly $a b$ initio, a city can ensure consuiners a continued supply at a fair price. The solution, however, carries the risks of monopolistic prices and practices by the franchisee, and financial harn and lost opportunities to potential competitors. It is these harms that are alleged in the natural monopoly cases. ${ }^{219}$

218. Cirace, supra note 123, 491-93. Cirace offers an economic analysis of how social policy norms can create natural monopolies and justify exclusion of competitors from the more profitable aspects of an essential industry.

219. In Hybud Equip. Corp. v. City of Akron, 654 F.2d 1187 (6th Cir. 1981), vacated and remanded in light of City of Boulder, 455 U.S. 931 (1982), for cxample, the city and county required all garbage collectors to deposit all eligible solid waste at the municipal recycling plant. Thc plant constituted a natural monopoly because competition would reduce volume to the point that multiple plants would not be feasible. Hybud Equip. Corp, 654 F.2d at 1190 . Plaintiffs alleged reduced business opportunities, noncompetitive pricing, and elimination of consumer choice. Id. In Community Builders v. City of Phoenix, 652 F.2d 823 (9th Cir. 1981), two cities were compelled by state law not to compete in providing water service. Presumably, multiple services would result in wasteful duplication of infrastructure and administrative costs. The plaintiff alleged that he was 
Cable television is a prime example of a local natural monopoly. Conventional financial wisdom holds that the costs of cable infrastructure are so high that supplying cable is unprofitable unless the supplier is assured a captive consumer audience. ${ }^{220}$ Cities thus often grant cable suppliers exclusive franchises. ${ }^{221}$ Sinilar natural inonopoly arguments may be made to justify zoning ordinances ${ }^{222}$ and territorial market divisions. ${ }^{223}$

Since a natural monopoly satisfies the inarket-failure branch of the first inquiry, assuming it is local, litigation in these cases will turn on the second inquiry - the legitimacy of the solution. The cases can profitably be divided into two classes-those in which the city participates in the monopoly and those in which the city grants an exclusive franchise to a private party.

\section{City Participating in the Monopoly}

Consider the example of Community Builders v. City of Phoenix. ${ }^{224}$ The Arizona cities of Phoenix and Scottsdale had each supplied water to customers in overlapping territories. The two cities agreed to a territorial division of their respective water supply systems. The plaintiff, a prospective developer, established that he was paying higher hookup fees than he would if the two cities were in competition. The cities prevailed on the grounds that the state had statutorily conferred its antitrust iinınunity upon them. Absent the immunization, however, the cities would most likely have justified their inarket division with a natural monopoly argument: duplicate piping systems and administrative networks would be too costly in overlapping systems.

Since the cities increase their revenues by virtue of their territorial division, they would fall into the second prong's "self-interested" category, and be denied automatic governmental nonliability. Their public welfare justifications would not necessarily be ignored, however. The

denied the opportunity to get service from the cheaper of the two cities. Id. at 825 . Reduced competitive opportunities are alleged in most municipal monopoly cases. See, e.g., Central Iowa Refuse Sys. v. Des Moines Metropolitan Solid Waste Agency, 715 F.2d 419, 423 (8th Cir. 1983) (solid waste disposal plant), cert. denied, $105 \mathrm{~S}$. Ct. 1864 (1985); Hopkinsville Cable TV, Inc. v. Pennyroyal Cablevision, Inc., 562 F.2d 543, 545 (W.D. Ky. 1982) (exclusive cable television franchise).

220. Cirace, supra note 123 , at 492 .

221. See, e.g., Hopkinsville Cable TV, Inc. v. Pennyroyal Cablevision, Inc., 562 F. Supp. 543 (W.D. Ky. 1982).

222. In Westborough Mall the court acknowledged that the city was too small to support two shopping centers. Westborough Mall v. City of Cape Girardeau, 693 F.2d 733, 737 n.1 (8th Cir. 1982), cert. denied, 461 U.S. 945 (1983).

223. See, e.g., Community Builders v. City of Phoenix, 652 F.2d 823 (9th Cir. 1981) (two cities agreed not to compete with their water supply services); see also Affiliated Capital Corp. v. City of Houston, 735 F.2d 1555 (5th Cir. 1984) (en banc), discussed supra at text accompanying note 214.

224. 652 F.2d 823 (9th Cir. 1981). 
level of skepticism toward such justifications would turn on the level of self-interest. If either city were generating a surplus and the territorial division contributed significantly to revenues, the city would be analyzed as a private party, losing all legitimacy to assert public welfare justifications. It would then lose the suit because of the per se rule against horizontal market division. ${ }^{225}$ If, on the other hand, the water services were financially self-contained and funded no other municipal subdivisions, the cities' self-interest would be less significant, and the analysis would move on to the third inquiry-the solution's effectiveness.

Note that the other two aspects of the second inquiry would not thwart the defendants' agreement. The plaintiff, building on Scottsdale territory, can complain of no externalities. Moreover, both the benefits (assured water supply under public control) and the burdens (lack of alternative suppliers and absence of competitive pressure for improvement) inure to residents of the two cities. Such internal redistribution of competitive burdens and benefits merits governmental nonliability when public purposes are advanced and the government does not delegate discretionary authority, as was the case here.

The Community Builders plaintiff would not prevail on the third inquiry-the effectiveness of the solution. Although other solutions might achieve greater efficiency, they would not inprove the plaintiff's situation. Once it is determined that a natural monopoly precludes competition, no reasonable alternative would provide plaintiff with a choice of competing water suppliers. Thus, under the proposed analysis, Scottsdale and Phoenix would prevail.

Alternative plaintiffs might fare better. ${ }^{226}$ Dwellers outside the borders of Scottsdale and Phoenix who are subject to the plan, although they may receive some benefit, suffer the effects of a territorial division by entities outside their influence. They would thus fall under the second inquiry's category of externalized burdens. If their burden is significant, the cities will lose. In that case, the alternative plaintiffs might argue for nullification of the agreement outside municipal borders. Alternatively, they could argue for a solution that permitted participation in economic decisionmaking, such as creation of a regional board of directors governing the water services. Potential competing water suppliers are unlikely to exist, but would also have grounds to complain, and their claims would require a inore careful analysis under the third inquiry. If such a competitor were able to provide water service so as to meet the area's needs, the cities inight have to consider opening up the market. ${ }^{27}$

225. See L. Sullivan, supra note $38, \S 80$.

226. This Comment does not consider the question of whether plaintiffs should have standing to raise the arguments of absent parties.

227. Consider in this regard Central Iowa Refuse Sys. v. Des Moines Metropolitan Solid Waste Agency, 715 F.2d 419 (8th Cir. 1983), cert. denied, 105 S. Ct. 1864 (1985). Fifteen lowa cities 


\section{Franchised Market Created by the City}

A different situation is presented when the governmental defendant creates, but does not participate in, the monopoly. A city might, for example, limit the number of licenses or franchises it distributes for taxicabs $^{228}$ or for ambulances. ${ }^{229}$ It may create zoning to limit the number of shopping centers, ${ }^{230}$ or it may carve out captive markets for cable television providers. ${ }^{231}$ In the absence of self-interest, the city action will be covered by governmental nonliability to the extent that there are no externalities. The argument for nonliability in this situation is strong: the city not only is not self-interested but also is presumably the best situated entity to determine the appropriateness of replacing competition with regulation. ${ }^{232}$ As with the market-participant scenario, to the extent anticompetitive burdens are directed internally, the city should not be held liable.

There is, of course, some irreducible external anticonipetitive burden because outside companies are limited in their ability to penetrate the market. This externality would entitle such companies to proceed to the third inquiry. The municipal defendant would have to prove that its franchising scheme minimizes the externalized burden. The focus will be on the procedures the city uses to allocate its franchises. These procedures should niaximize opportunities for competition, especially by

created a joint solid-waste disposal company and granted it exclusive waste disposal rights within their borders. The court, construing City of Boulder liberally, found the cities immune by virtue of state statutes authorizing such regional waste facilities.

Absent such delegated immunity, however, the plaintiff would be able to allege anticompetitive harm. Much of the anticompetitive harm would be borne by the municipal residents, and would be forgiven by the internal redistribution rationale. The remaining harm to plaintiff as a competitor, although relatively minimal, would be external, and would be determined under the third inquiry. The court would accept the desirability of providing waste removal services, and would analyze whether territorial exclusivity was the least anticompetitive alternative. The cities had made a strong showing that exclusivity was necessary to the financial viability of the project. The exclusivity provisions were narrowly tailored to minimize anticompetitive burdens. Although all waste had to be disposed of at the joint treatment facility, trash collection and transportation remained competitive. Id. at 423 . Additionally, the restriction permitted self-correction by the market. When the bonds used to finance construction of the facility were paid off, the exclusivity provisions would expire. Id. at 422 n.7. While a full examination of less anticompetitive alternatives is beyond the scope of this Comment, the fact that most of the anticompetitive burden is internal and that the provisions are narrowly tailored argues heavily against liability.

228. See, e.g., Campbell v. City of Chicago, 577 F. Supp. 1166 (N.D. Ill. 1983).

229. See, e.g., Gold Cross Ambulance \& Transfer v. City of Kansas City, 705 F.2d 1005 (8th Cir. 1983), cert. denied, 105 S. Ct. 1864 (1985).

230. See, e.g., Westborough Mall, Inc. v. City of Cape Girardeau, 693 F.2d 733 (8th Cir. 1982), cert. denied, 461 U.S. 945 (1983).

231. See, e.g., Hopkinsville Cable TV, Inc. v. Pennyroyal Cablevision, Inc., 562 F. Supp. 543 (W.D. Ky. 1982).

232. When the city sells its franchises, it may appear self-interested. In this event, further inquiry is necessary to determine if the city's revenues are greater under the regulated economy than they would be under an analogous free market. $C f$. text accompanying note 212 (regarding selfinterest). 
outside providers. Where little capital outlay is involved, licenses should be of short duration to permit turnover. Application for licenses should be widely publicized and should not have unnecessary eligibility requirements. As long as a city attempts to maximize free competition for the licenses, it will not be liable in antitrust for imposing a franchising system.

The last three sections have applied the proposed analysis to three categories of cases in which municipalities tend to be antitrust defendants: where the city is a market participant, where the city facilitates private restraints on competition, and where the city resolves a natural monopoly problem by entering the market or licensing it. These tliree categories are neither complete nor exclusive; they merely serve to illustrate the applicability of the proposed analysis to currently litigated situations. It is hoped the discussion demonstrated both the feasibility of the analysis and its utility in identifying the relevant issues. The next section will treat a narrower category in more detail-antitrust challenges to local rent control legislation.

\section{Rent Control}

Several post-City of Boulder lawsuits have attacked local rent control statutes, claiming that the statutes constitute price fixing in violation of the Sherman Act. In New York City, a federal district court found state authorization (and therefore immunity from challenge) for the local rent control regulations which were enacted pursuant to the state's Local Emergency Housing Rent Control Act. ${ }^{233}$ In California, suits challenged rent control ordinances in San Francisco and Berkeley. ${ }^{234}$ The California Supreme Court decided that Berkeley's ordinance did not violate the antitrust laws; ${ }^{235}$ however, the United States Supreme Court has noted probable jurisdiction. ${ }^{236}$ Landlord groups are considering bringing similar actions in New Jersey and the District of Columbia. ${ }^{237}$

Rent control legislation presents a particularly difficult case for determining liability because the two competing interests are so strong. In some ways, antitrust challenges seem inappropriate. Rent control is economic regulation, a traditional government function. Because rent

233. Brontel, Ltd. v. City of New York, 571 F. Supp. 1065 (S.D.N.Y. 1983), aff'd sub nom. Rent Control Memorial Corp. v. City of New York, 742 F.2d 1439 (2d Cir.), cert. denied, 105 S. Ct. 248 (1984).

234. For a description of the San Francisco case, see San Francisco Chron., Jan. 3, 1984, at I, col. 3; id. at 22, cols. 5-6. The issue was raised for the first time in Fisher on appeal. See Fisher v. City of Berkeley, 37 Cal. 3d 644, 653, 693 P.2d 261, 271, 209 Cal. Rptr. 682, 691-92 (1984), prob. juris. noted, 105 S. Ct. 2653 (1985) (No. 84-1538).

235. Fisher v. City of Berkeley, 37 Cal. 3d 644, 693 P.2d 261, 209 Cal Rptr. 682 (1984).

236. Fisher v. City of Berkeley, 105 S. Ct. 2653 (1985) (No. 84-1538).

237. Swallow, Debate Already Starting on D.C. Rent Control Due for Renewal in 85, Wash. Post, Sept. 29, 1984, at F1, col. 1; id. at F16, col. 2. 
control is an enactment rather than a business activity, it is unlike actions traditionally held to violate the Sherman Act; therefore, existing precedent does not immediately compel a finding of hability. Moreover, rent control strongly imphicates policies of local government autonomy. On the other hand, rent control is highly anticompetitive-it fixes the maximum price of a product on the open market. Pricefixing is the paradigm activity prohibited by the antitrust laws. ${ }^{238}$ As an activity which has a primary purpose or effect of preventing price competition, rent control is a per se violation of the Sherman Act. ${ }^{239}$ The proposed analysis helps resolve these conflicting viewpoints.

\section{First Inquiry ${ }^{240}$}

A city may justify anticompetitive regulation only if it identifies a nonanticompetitive or nonprotectionist goal. Such a showing is essential for cities desiring rent control ordinances. The effect of rent control is to benefit one group (renters) at the expense of another (landlords). This confers an unearned financial benefit on incumbent tenants. Rent control imposes anticompetitive burdens upon the landlords, who are deprived of market-rate returns on their property, and on prospective tenants, who are foreclosed from competing by bid for rental housing units. It also destroys allocative efficiency in the rental market by depressing prices (rents) below those warranted by demand. Absent a nonprotectionist justification, the rule of reason would apply; the net anticompetitive effects of rent control would then result in liability. ${ }^{241}$ Thus, the first

238. NCAA v. Board of Regents, 104 S. Ct. 2948, 2964 (1984).

239. L. Sullivan, supra note $38, \S 67$.

240. The economic arguments in this section are not intended to be complete; rather, they serve to illustrate arguments that arise from a conflict between municipal policies and antitrust goals.

241. Of course, a successful attack on a rent control ordinance would also have to prove the other elements of antitrust liability, such as an effect on interstate commerce and concerted action.

The interstate commerce nexus has become increasingly easy to satisfy. Recent Supreme Court cases have found the Sherman Act applicable to local housing markets. See, e.g., McLain v. Real Estate Bd., 444 U.S. 232 (1980) (holding that the Sherman Act is applicable to an alleged conspiracy to fix local real estate brokerage fees). The Court wrote that jurisdiction lies when the economic activities affected by the challenged conduct "have a not insubstantial effect on the interstate commerce involved." Id. at 246; see also Goldfarb v. Virginia State Bar, 421 U.S. 773 (1975) (Sherman Act covers agreement to fix prices of title examinations prefatory to local real estate transactions).

The concerted action requirement might be shown either as a conspiracy among tenants or as a combination between the city and landlords. The tenant conspiracy would be a horizontal pricefixing cartel enforced by the city in response to complaints by individual tenants. The city/landlord theory is based on retail price maintenance cases in which the Court has stated that even unwilling compliance in a price-fixing scheme satisfies the concerted action requirement. See, e.g., Copperweld Corp. v. Independence Tube Corp., 104 S. Ct. 2731, 2738 n.9 (1984); Albrecht v. Herald Co., 390 U.S. 145, 150 n.6 (1968). To the extent the requirement includes a "meeting of the minds" component, see Monsanto Co. v. Spray-Rite Serv., 104 S. Ct. 1464, 1471 n.9 (1984), this requirement could be met by landlords' compliance after enforcement action. 
issue under the proposed analysis is the existence of a nonprotectionist justification for rent control.

The prohibition on specifically anticompetitive goals eliminates some otherwise plausible justifications for rent control. The city may not claim as a goal, for example, the norm of protecting poor tenants from high rents. That would constitute protectionism, and bespeaks a private rather than public purpose. Nor would it suffice for the government to argue that ethical norms require removing life's necessities from the vicissitudes of the marketplace. No matter how legitimate or compelling this argument may appear, it is at bottom a claim that competition is bad.

More specific arguments abound which, in the proper circumstances, demonstrate that the competitive market is no longer functioning. The model market assumes an ability of supply to meet demand. ${ }^{242}$ In many rent-controlled cities, supply forces have broken down. High interest rates, real estate speculation, bank lending policies, and tax laws may have raised entry barriers to the housing market so that construction of rental housing is no longer economical. In other cities, existing development and geographic barriers may have eliminated developable land. Such supply failure, demonstrated by very low vacancy rates, would constitute a market failure satisfying the first inquiry.

Alternatively, in a period of rapidly escalating rentals, a city may adopt a social norm of stability and neighborhood preservation to justify rent control. Slow change in housing patterns is well within a city's public welfare aims-it promotes civic peace and allows orderly planning for the provision of services and the construction of an infrastructure. Rapid neighborhood change makes it difficult, for example, to provide schooling and transportation, and can destroy subcultures that may be critical to a city's identity and goodwill. Thus, elimination of rapid rent fluctuations, together with neighborhood stability, would be a nonanticompetitive goal justifying rent control.

The defendant cities may also argue that rent control would serve to correct an externality which discourages volunteerism. Neighborhood improvement organizations often make vital contributions to civic wellbeing by supplementing municipal functions. The organizations may, for example, organize tree-planting, volunteer at the local school, or conduct anti-crime programs. As neighborhood beauty and safety increase, the desirability of the neighborhood will increase and the land value will rise. In rental neighborhoods, the increase in land value resulting from such neighborhood improvement will inure to nonparticipating landlords. Furthermore, in a competitive market, the increased property value will support higher rents. Some of the residents participating in the volunteer

242. See supra note 146 (free resource mobility axiom). 
efforts will be forced to leave due to the increased rental costs. This is not only unfair, it also discourages volunteerism. Thus, the desire to preserve the incentive for neighborhood improvement is another example of a nonanticompetitive goal justifying rent control. ${ }^{243}$

A more difficult issue under the first inquiry is whether the problem is local. In some cases, the governmental unit enacting the ordinance will have jurisdiction over only a portion of the relevant housing market. The market definition questions involved are difficult, but familiar to antitrust litigation. ${ }^{244}$ The geographic extent of the problem will depend, of course, on the particular social norm theory advanced, as well as on the peculiarities of the local housing market, job market, and transportation systems.

In some areas, the housing issues have a more regional than local character. Particularly when the job and housing markets span several geopohitical entities, it may be difficult for any one such entity to characterize the problem as local. Critical factors will mclude the proximity of the geopohtical entities, transportation links between them, and similarity of housing stock (in terms of price range and type). When the housing market is truly regional, the locality principle would deny a local government the legitimacy to impose a local solution with anticompetitive effects.

On the other hand, housing issues have an inherently local flavor. Land has traditionally been regulated locally. ${ }^{245}$ More fundamentally, land is the means by which the jurisdictional reach of the local governinent unit is defined. Functionally, this tradition may pohtically disable state governments from responding to land use problems, necessitating local government action. ${ }^{246}$ Thus, despite potentially complicated litigation, courts would frequently be justified im finding a local problem, enabling the defendant to claim governmental legitimacy under the first inquiry.

243. Defendants would be free to argue that if neighborhood improvement really increased property values, landlords would pay workers to provide services in the neighborhoods in which the landlords own property. There are several problems with this argument. First, hired workers are more expensive than volunteers and might not generate a sufficient increase in property value to justify their cost. Second, it is unlikely that paid employces can replicate the benefits of neighborhood involvement. Programs such as a neighborhood watch program, zoning-commission advisory committee, or an after-school program may require the participation and knowledge of local residents. Third, because absentee landlords lack the social network that neighbors have, they may be more tempted to "freeload" by enjoying the benefits of the neighborhood-improvement programs without participating.

244. See supra note 157.

245. Rose, supra note 181 , at 839 .

246. Ideally, regional intergovernmental solutions may be the most effective means of responding to land-related market failures. Political resistance to such innovations, however, precludes the consideration of such solutions as serious alternatives for the purposes of a lawsuit. 


\section{Second Inquiry}

Under the second inquiry, the litigation will then turn to the legitimacy of the rent control ordinance as a solution. The first part of this inquiry-whether the municipal action is self-interested-is easily decided in favor of the municipality. The benefits of a rent control ordinance do not inure to the city itself, but rather to a group within the city. Tracing the anticompetitive burdens to determine whether they are externalized or internally redistributed is more difficult. Much of the tracing burden rests on the landlords. As to those landlords who reside in the city, the ordinance redistributes among the governed, resulting in no mumcipal liability. With respect to nonresident landlords, the situation is shghtly more problematic, but the politically realistic view ${ }^{247}$ suggests that all landlords should be considered residents for the purposes of the proposed analysis. Landlord interests are almost certain to be well represented in decisionmaking, particularly concerning such a controversial and well-publicized issue as rent control. Furthermore, landlords derive benefits from the municipality in terms of municipal services which constitute an element of their property values. Sonie general economic benefits from the city therefore benefit the landlords as well. As recipients of both burdens and benefits, and as political participants, landlords should be considered members of the municipality. Accordingly, the internal redistribution model of the second inquiry is niore apphicable than the externalization model, at least when landlords are the complainants.

The internal redistribution analysis, it should be remembered, includes a requirement that the anticompetitive regulatory scheme be actively supervised by the city. ${ }^{248}$ The city can prevail only if it actively supervises rents. This does not require each housing unit to be individually appraised. The common method is to define base rents by market value at a given point in time, and then set rents as a percentage above the base. ${ }^{249}$ This is a fair, administrable method. The percentage must be supervised by a representative body in order to ensure that the purpose of the systen remains public and not protectionist.

The appropriate analysis under the second inquiry will vary with the plaintiff's identity. Developers and others who seek to create new rental housing will more clearly bear an externalized anticompetitive burden if they are based outside the city. Their costs of construction will be tied to the larger regional market, but their potential returns will be artificially depressed by local rent control. Their local rate of return will be too low to warrant investnient, and the local market will be foreclosed to then.

247. See supra text accompanying note 181 .

248. See supra text accompanying notes $176-80$.

249. For a discussion of the rate-setting mechanisms, see infra note 254 . 
Two other groups which bear some of rent control's anticompetitive burden are clearly external under this inquiry-prospective tenants and neighboring communities. In this inquiry, the former group properly includes only newcomers to the city who desire to rent. Newcomers are restricted in exercising political and economic muscle to secure rental housing. The extent of their burden depends not only on the number of recent immigrants, but on their relative wealth. For some prospective tenants, however, economic power owes its very existence to rent control: absent the ordmance, housing costs might be prohibitive for them anyway.

The magnitude of the anticompetitive burden imposed on neighboring communities, although clearly external, is even more uncertain. If rent control forecloses rental opportumities in the defendant city, prospective tenants are likely to search nearby cities. This will increase the rental housing demand in those cities, placing upward pressure on rents and burdening tenants in those communities. On the other hand, these seekers are likely to be wealthier than the residents of the defendant city who would be forced out absent rent control. Rent control inight therefore assist neighboring cities by insulating them from the need to provide low-inconie housing.

Thus, the second inquiry reveals three sources of externalities: frustrated potential developers; immigrants who would be wilhing to pay higher rent to secure housinig; and neighboring communities that bear the possible adverse impacts on their housing markets. The presence of sonie externahities precludes the defendant fron 1 prevailing after the first two inquiries. If evidence at trial reveals that these externalities represent the bulk of the anticompetitive displacenient, or that they are large conipared to the city's economic benefit, the municipality should be treated as a private party. Presuming, however, that these externalities are minor relative to the benefits, the litigation must continue to the third mquiry.

\section{Third Inquiry}

When the litigation reaches the third inquiry, it means that the defendant city has established that it is the appropriate governniental entity to regulate the problen 1 and that it has chosen a solution that does not impose disproportionate anticompetitive injury on outsiders. What reniains to be decided is whether the iniposed externalized harns justify holding the city liable anyway. This inquiry focuses on the effectiveness of the city's action, and on whether the city has effectively minimized the externalities. The rent control analysis here will focus on the external burden borne by the three groups identified in the second inquiry: developers; inımigrants; and neighboring communities. 
Many rent control statutes eliminate entirely the burden on potential developers by exempting newly-built housing. ${ }^{250}$ Alternatively, a city might internalize the burden by providing subsidies for new construction. The subsidy might be in the form of a direct paynent, or might take the form of exemption from other burdensome municipal regulations, such as zoming restrictions or assessments. This burden of reduction/internalization could be accomplished without harm to the city's goals. Although the resultant uncontrolled housing appears antithetical to affordable housing policies, the net effect actually supports those policies by facilitating new construction. Although new construction may be contrary to some of the other goals justifying rent control, such as neighborhood stability, the impact of what would probably be only a few new umits in any one neighborhood subunit will have a minimum impact on the neighborhood as a whole. A new construction exemption or subsidy minimizes or limits an anticompetitive externality without harming inunicipal goals, and would thus be required by the proposed analysis.

As to the externalized burden on immigrants, it might be argued that an exemption for newly-vacated units ${ }^{251}$ would reduce that burden by providing at least a small foruin for competition. In particular, the externahity imposed upon immigrants could be abated because they are free to exercise economic muscle in coinpeting for these apartments. While einpirical research is beyond the scope of this Coniment, the above argument appears flawed in two respects. Vacancy decontrol directly reduces the effectiveness of rent control, and it may increase, rather than decrease, externalities. These two points are discussed in turn.

Although it may ease the immigrants' externality, vacancy decontrol would directly conflict with the city's goals in enacting rent control. For city residents competing for newly-vacated city apartments, the inflated rents would be higher than they would have been without rent control. This runs counter to affordable housing goals, and may bring other burdens to tenants. Vacancy decontrol encourages evictions because the owner may greatly mcrease revenues with the new tenant. It iminobilizes residents by making relocation within the city unaffordable. Such decontrol can slowly destroy a city's cultural or artistic identity in low-incoine neighborhoods: whenever a tenant in such an area vacates, she is replaced by a higher-income individual able to afford the inflated

250. See, e.g., Santa Monica Rent Control Law, art. xviii, §1801(c)(5), reprinted in J. Gilderbloom, ReNT CoNTRol: A SourCEBOoK 304 (1981). The Santa Monica law exempts newly constructed units. While most new construction exemptions are permanent, some municipalities exempt only the initial rental. See generally M. LETT, RENT CONTROL: CONCEPTS, REALITIES, AND MEChanisms $91-92$ (1976).

251. Such an exemption is known as vacancy decontrol. In vacancy decontrol, the landlord is free to set a market price for a rental unit when a tenant moves out, but is limited to the controlled percentage increase in rent during the term of any individual tenant. 
rent, but unlikely to contribute to the neighborhood's special identity. ${ }^{252}$

Moreover, even if vacancy decontrol eases the externality for immigrants, it may increase the burden on neighboring communities. Since it creates no new housing units, vacancy decontrol fails to ease the excess of demand over supply. It is not, therefore, clear that vacancy decontrol reduces the total externalities. By permitting a higher rent for the few available units, the city is "skimming the cream" off the tenant market. Neighboring areas continue to bear the same housing demand, but must satisfy less affluent seekers. The burden on immigrants is reduced at the expense of increasing the burden on neighboring communities. Thus, vacancy decontrol would not be required by the third inquiry because it acts to shift, rather than to reduce, externahities, and because it directly impedes the mumicipal pohicies motivating a rent control ordinance.

Other statutory devices are available, however, which minimize the overall anticompetitive burden of rent control, and, therefore, reduce externalities. Sunset provisions, common to some ordinances, ${ }^{253}$ provide for the termination of rent control once vacancy rates reach a certain level. A sunset provision could be court-mandated in a Sherman Act challenge-it does not impede legitimate nunicipal policies, but rather ensures that the anticompetitive action reaches no further than its justifying local problem.

Similarly, a city should allow controlled rents to increase slowly. Such a provision would be a regulatory attempt to replicate an ideal market. $^{254}$ It would shield tenants and neighborhoods from the dislocations caused by oscillations in supply and demand, but preserve the relative price of housing, ${ }^{255}$ both as to the tenants' income, and as between neighborhoods. Allowing a controlled rent mcrease also would minimize some of the anticompetitive effects of rent control, and would help land-

252. A city might also claim that vacancy decontrol is contrary to local policy because it allows the wealthy to occupy all available housing units, monopolizing the rental market and driving the less affluent from the city. Such ethical arguments, however, have no place in antitrust analysis. The antitrust laws make competition the fundamental policy of the national economy, and the above argument is tantamount to arguing that competition is itself inappropriate in the housing market.

253. For example, the Berkeley rent control statute at issue in Fisher contained such a provision. Fisher v. City of Berkeley, 37 Cal. 3d 644, 653, 693 P.2d 261, 268, 209 Cal. Rptr. 682, 691 (1984), prob. juris. noted, 105 S. Ct. 2653 (1985) (No. 84-1538).

254. Many cities allow rents to increase in some manner that roughly tracks inflation. In an ideal competitive market, rents would depend on landlord costs and rate of return in alternative investments. Some cities attempt to replicate such complex variables when setting maximum permissible rents. Others tie rents to inflation as a more readily-administrable compromise. In order to avoid rents which are confiscatory to landlords, these cities generally have special provisions to ensure landlords a reasonable return on investment when the inflation-indexed rates are inadequate. The ordinance challenged in Fisher had such a provision. Id. at 653,693 P.2d at 270, $209 \mathrm{Cal}$. Rptr. at 691 . For a general discussion of methods of setting maximum rents, see M. LETT, supra note 250, at $95-103$ (1976).

255. If housing costs have, on a national level, changed in proportion to the average income, this also could be considered in setting rents. 
lords maintain an adequate return on investment. ${ }^{256}$ Finally, it preserves competition at the lowest income levels.

Thus, several methods exist whereby a city might reduce externalities without reducing the effectiveness of its rent control program. In litigation proceeding to the third inquiry, a court could require a city to include in its rent control program a sunset provision and an exemption for new construction. With these provisions included, a rent control ordinance should not subject a city to liability in antitrust.

\section{E. Conclusion}

The preceding economic analyses are admittedly oversimplified and subject to various rebuttals. The purpose of the above discussion is not to replicate the complexity of economic analysis endennic to antitrust litigation, but rather to illustrate how the analysis outlined earlier would focus the inquiry. In actual higation, similar arguments could be expected. It is hoped that the examples demonstrate that such a methodology can recognize the unique pubhic welfare goals of inunicipal defendants while facilitating analysis of antitrust considerations.

\section{$\mathrm{V}$ \\ The Exemption/Preemption Debate}

Much debate has addressed whether the Parker/City of Boulder doctrine should be deeined a doctrine of "exemption" or a doctrine of "preemption."257 This Comment maintains that Parker and City of Boulder do not fit neatly into either of these doctrinal categories. The state action immumity doctrine is a unique doctrine of protection; ${ }^{258}$ attempts to characterize it as either exemption or preemption are intellectually interesting but misplaced. This section will explain exemption and preemption, but demonstrate that the Parker/City of Boulder doctrine is actually an example of neither.

Exemption apphes when Congress creates an exception from an enactment. Where the original enactment would prohibit a certain activity, the exemption saves that activity. When a litigant's claim to the protection of an exemption fails, the litigant will be found in violation of the law.

Preemption, in contrast, is a consequence of the supremacy clause. $^{259}$ A state statute is preempted by a federal statute when the two

256. Where the basic method of increasing rents fails to guarantee a landlord an adequate return, special provisions must be employed. See M. LETT, supra note 250, at 96.

257. See, e.g., Conant, supra note 93; Note, supra note 184.

258. See infra text accompanying note 272 .

259. The supremacy clause of the U.S. Constitution, art. VI, $\S 2$, provides that the laws of the United States "shall be the supreme Law of the Land . . . [the] Laws of any State to the Contrary notwithstanding." Preemption is thus a consequence of federalism. 
statutes are in conflict. ${ }^{260}$ State statutes and local government ordinances are analyzed identically under preemption analysis. ${ }^{261}$ A finding of preemption causes the nullification of the offending statute. Justice Rehnquist's dissent in City of Boulder argued that Parker and its progeny were based upon preemption doctrine, while the City of Boulder majority, in his view, erroneously interpreted them as exemption cases. ${ }^{262}$ Accordingly, Justice Rehnquist contended that city ordinances should be treated no differently than state statutes, and that city ordinances that fail the Parker state action requirements should be denied effect, but should not result in a violation of the antitrust laws. ${ }^{263}$

Most Supreme Court cases do not fit neatly into either the preemption or exemption rubrics. Their language has been thoroughly ambiguous. Parker itself used both "rendered mvalid" 264 and "rendered unlawful"265 to describe the Sherman Act's effect on unprotected state laws. The Parker Court's emphasis on the fact that the state did not enter into a conspiracy in restraint of trade ${ }^{266}$ suggests the Court was viewing the case as a question of violation (i.e.,. exemption). But a parsing of Parker and its progeny provides equal evidence for the opposmg view. Nor are the facts of the cases dispositive. In the cases denying immunity, the procedural posture and the requested remedy obscure whether preemption or exemption was at issue. ${ }^{267}$ Finally, the Court habitually cites preemption cases and exemption cases imterchangeably. In City of Boulder, the majority, per Justice Brennan, urged comparison of an exemption case, National Society of Professional Engineers v. United States, ${ }^{268}$ with a preemption case, Exxon Corp. v. Governor of Maryland. ${ }^{269}$ And in Rice v. Norman Williams Co., ${ }^{270}$ a preemption case, the

260. A state statute will also be preempted when the federal government has exclusively occupied the field.

261. See, e.g., Burbank v. Lockheed Air Terminal, Inc., 411 U.S. 624 (1973).

262. Community Communications Co. v. City of Boulder, 455 U.S. 40, 68 (1982) (Rehnquist, J., dissenting).

263. See Fisher v. City of Berkeley, 37 Cal. 3d 644, 660 n.8, 693 P.2d 261, 275 n.8, 209 Cal. Rptr. 682, 696 n.8 (1984), prob. juris. noted, 105 S. Ct. 2653 (1985) (No. 84-1538); Cirace, supra note 123, at 488; Conaut, supra note 93; Note, supra note 184, at 162-64; Note, Municipal Antitrust Liability After Boulder, 36 OKLA. L. REv. 827, 834 (1983).

264. Parker v. Brown, 317 U.S. 341, 344 (1943). This language suggests preemption.

265. Id. at 352 . This language suggests exemption.

266. Id.

267. Although a detailed analysis of the cases is beyond the scope of this Comment, in many of them the plaintiff sought to stop enforcement of an anticompetitive statute. See, e.g., California Retail Liquor Dealers Ass'n v. Midcal Aluminum, Inc., 445 U.S. 97 (1980) (injunction against enforcement of state-authorized but unsupervised wine price fixing system); Goldfarb v. Virginia State Bar, 421 U.S. 773 (1975) (injunction against enforcement of state bar's minimum fee schedule). An injunction against enforcement is consistent with either a preemption statute or a statute struck down for violating the antitrust laws. Community Communications Co. v. City of Boulder, 455 U.S. 40, 64-65 (1982) (Rehnquist, J., dissenting).

268. 435 U.S. 679 (1978).

269. 437 U.S. 117 (1978). 
Court, per Justice Rehnquist, cited violation cases to explain its analysis. $^{271}$

The better view is that Parker and City of Boulder represent a unique doctrine of protection. Although the City of Boulder opinion uses the word "exemption," its author, Justice Brennan, explained later that that word is a mere "shorthand" for Parker's holding. ${ }^{272}$ Furthermore, the Court's chief proponent of the preemption view appears to have conceded the point. Justice Rehnquist, in a footnote to his dissent in Rice, authored the Court's sole word on the relationship between Parker doctrine and preemption doctrine. ${ }^{273}$ The footnote is clearly inconsistent with the proposition that Parker is either a preemption or an exemption case.

The Rice Court held that a Cahifornia statute imposing a regime of vertical nonprice restramts was not preempted by the Sherman Act. The Rehnquist footnote said that the Court's holding obviated the need to consider whether the statute may be "saved from invalidation under. . . Parker."274 Clearly, if the Parker doctrime can hypothetically save a preempted statute, the doctrine cannot be merely "a matter of federal preemption." 275 The same footnote, however, also negates the proposition that the Parker doctrine is solely one of exemption/violation. If it were only that, it would not have the force to save an otherwise preempted statute. A statute preempted by the Sherman Act would not be revived merely because the state did not itself violate the Act in enacting or implementimg the statute. The Rice footnote thus confirms that the Parker doctrime is more than mere exemption and different from nonpreemption.

The debate as to whether the Parker/City of Boulder doctrine is one of preeinption or exemption may be of great theoretical interest, but it misses the point. The Court has developed a specific doctrine tailored to the interaction of the federal antitrust laws with the activities of state and local governments. The doctrine differs in two significant respects from preemption. First, state regulation has nonrelative iminunity. Once it passes the threshold tests, its purposes and importance are not examined. Preemption analysis, in contrast, involves balancing the means and ends

270. 458 U.S. 654 (1982).

271. Rice, 458 U.S. at 659.

272. City of Lafayette v. Louisiana Light \& Power Co., 435 U.S. 389, 393 n.8; see also Kurek v. Pleasure Driveway \& Park Dist., 557 F.2d 580, $587 \mathrm{n.5}$ (7th Cir. 1977), vacated and remanded in light of City of Lafayette, 435 U.S. 992 (1978), reinstated as to antitrust issues, 583 F.2d 378 (7th Cir. 1978), cert. denied, 439 U.S. 1090 (1979); Century Fed. v. City of Palo Alto, 579 F. Supp. 1553, 1555 \& n.5 (N.D. Cal. 1984).

273. Rice, 458 U.S. at 662 n.9.

274. Id.

275. City of Boulder, 455 U.S. at 63 (Rehnquist. J., dissenting). 
of the conflicting enactments. ${ }^{276}$ Second, the Court's doctrine treats local governments differently than state governments. A preemption analysis draws no such distinction. Perhaps out of practical necessity ${ }^{277}$ the Supreme Court has affirmatively declined to apply preemption doctrine in most antitrust cases. ${ }^{278}$ Yet the Parker/City of Boulder doctrine is also distinct from exemption analysis, as explained by Justice Brennan in City of Lafayette ${ }^{279}$ and as implied by Justice Rehnquist's footnote in Rice. ${ }^{280}$ Parker/City of Boulder doctrine therefore is a unique doctrine protecting state and local governments from the stringent prohibitions of the Sherman Act.

The analysis suggested by this Comment for litigating antitrust suits against municipalities derives from the substance of antitrust doctrine, including the state action cases, and from the policy of preserving local autonomy. Although written using the Supreme Court's language of "exemption," the analysis applies whether the Parker doctrine is labelled preemption or exemption.

\section{CONCLUSION}

When the Supreme Court held that local governments can be sued under the antitrust laws, it suggested that cases involving government defendants should be analyzed differently than cases involving purely private defendants. Existing antitrust doctrine, developed with private defendants in mind, is inadequate to consider the special economic role played by local governments. The Court gave little guidance, however, in adapting antitrust doctrine to municipal defendants. This Comment proposes three inquiries that take cognizance of the public welfare role of local government. The resulting analysis determines whether the government's public welfare purposes justify its anticompetitive actions. If not, the municipal defendant is treated as a private party.

The first inquiry determines whether the defendant is the appropriate governmental unit to undertake the challenged action. To prevail, the defendant must show that its action responded to a nonprotectionist

276. See J. Nowak, R. Rotunda \& J. Young, supra note 118, at 293-94 (The test is whether "the state law 'stands as an obstacle to the accomplishment and execution of the full purposes and objectives of Congress.' " (quoting Hines v. Davidowitz, 312 U.S. 52, 67 (1941)); accord L. TRIBE, supra note $118, \S \S 6-23$ to $6-24$, at $376-79$.

277. The antitrust laws are so broad that all state activities interfere with them; straightforward application of preemption doctrine would eviscerate state power.

278. Admittedly, the Court has not declared preemption analysis inapplicable to antitrust challenges. But the Court has only once in recent years been willing to entertain a Sherman Act preemption challenge, and in so doing set such a high threshold that future challenges are likely to be discouraged. Rice v. Norman Williams Co., 458 U.S. 654 (1982). The Court in Rice held that a statute will be preempted only "when the conduct contemplated by the statute is in all cases a per se violation." Id. at 661 .

279. See supra text accompanying note 272 .

280. See supra text accompanying notes 273-75. 
local problem. The second inquiry asks whether the action's anticompetitive impact takes on a governmental or private character. To be governmental, the action must not inure to the direct benefit of the defendant. Furthermore, the anticompetitive harms of the action must be distributed inside the governmental unit rather than be externalized. Finally, the defendant must actively supervise its anticompetitive regulations.

If the defendant prevails on both inquiries, it is not liable. If it loses, it is subject to the same antitrust analysis as a private party. A municipal defendant which loses under the second inquiry due to either minor selfbenefit or minor externalized anticompetitive harm, however, gets one more chance to justify its action under the third inquiry. The defendant city can still prevail by demonstrating that it has minimized the self-benefit or externalization as far as possible without impairing the effectiveness of the challenged activity.

This Comment applied the proposed analysis to many municipal activities commonly challenged in antitrust. The examples demonstrate that the analysis can resolve the confiict between the dual goals of a competitive marketplace and autonomous local governments while being supportive of both.

Robert Eisig Bienstock*

* B.A. 1978, State University of New York at Stony Brook; J.D. 1985, Boalt Hall School of Law, University of California, Berkeley. 